University of Rhode Island

DigitalCommons@URI

Open Access Master's Theses

1993

\title{
Art and Textile Design: The Onondaga Silk Company's "American Artist Print Series" of 1947
}

Amy C. Lund

University of Rhode Island

Follow this and additional works at: https://digitalcommons.uri.edu/theses

\section{Recommended Citation}

Lund, Amy C., "Art and Textile Design: The Onondaga Silk Company's "American Artist Print Series" of 1947" (1993). Open Access Master's Theses. Paper 1566.

https://digitalcommons.uri.edu/theses/1566

This Thesis is brought to you for free and open access by DigitalCommons@URI. It has been accepted for inclusion in Open Access Master's Theses by an authorized administrator of DigitalCommons@URI. For more information, please contact digitalcommons-group@uri.edu. 


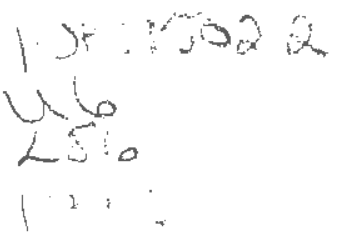

ART AND TEXTILE DESIGN:

THE ONONDAGA SILK COMPANY'S "AMERICAN

ARTIST PRINT SERIES" OF 1947

BY

AMY C. LUND

A THESIS SUBMITTED IN PARTIAL FULFILLMENT OF THE REQUIREMENTS FOR THE DEGREE OF

MASTER OF SCIENCE

IN

TEXTILES, FASHION MERCHANDISING, AND DESIGN

UNIVERSITY OF RHODE ISLAND

1993

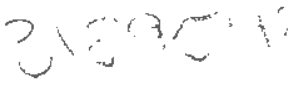


ABSTRACT

In the spring of 1947, the Onondaga Silk Company collaborated with the Midtown Galleries of New York City to create the "American Artist Print Series." This collaboration, drawing upon the familiar practice of using well-known international artists as textile designers, resulted in a collection of dress fabrics inspired by works of lesser-known American artists. The goal was to bring American art to the fashionable consumer. Ideas and influences from art, industrial design, textile design and fashion design from the first half of the twentieth century are reflected in this series.

This study explores the development of the "American Artist Print Series" starting with the conception of the idea of using American artists' works as the inspiration for fashionable textile fabrics. Paintings from selected artists represented by the Midtown Galleries were chosen by the silk company. Industrial designers then adapted the motifs for screen printing on silk and rayon fabrics. Finally, leading contemporary American ready-to-wear designers, including sophie of saks, Nettie Rosenstein, and Jo copeland, created fashionable garments with the fabrics. The complete series, from paintings to 
finished garments, was presented to the American public through exhibition in major museums and department stores.

The Onondaga venture was a commercial success, encouraging continued collaboration with the Midtown galleries and its artists. This study recognizes the contribution of a New York Art Gallery and of a little-known American textile company to both the fields of textile design and art history. It may encourage future study of other designs produced through similar processes; further study of design in the 1940s, a period which has been little recognized in scholarly literature is needed. Primary sources included paintings, textile samples, extant garments and photographic representations, letters, notes, and the original label copy from the exhibition. Secondary studies and contemporary articles were consulted for information concerning early twentieth century art, industrial design, textile design, and fashion design. 


\section{ACKNOWLEDGEMENTS}

I thank the members of the Graduate Program in Textiles, Clothing, and Related Art, both professors and fellow students, for their support and encouragement of my studies in this field. I extend special appreciation to my thesis committee members: Linda Welters for her direction and persistence, Margaret Ordoñez for her encouragement, and Ron onorato for his help with the art historical viewpoint. I would like to thank David Smith for his insight into the world of these artists.

I also thank Pam Parmal at the Museum of Art of the Rhode Island School of Design for pointing me in the direction of these textiles and cathy carver for the photographing the textiles in the collection for me; all photos of textile samples from RISD are from slides. I appreciate the help and cooperation of the staffs of the textile departments in museums that I contacted and the individuals involved in the original collaboration. 


\section{PREFACE}

This thesis was written in the manuscript format as prescribed by the University of Rhode Island Graduate School. It is the intention of the author to submit it upon its completion and acceptance by the University of Rhode Island to DRESS, the annual journal of the Costume Society of America. 
TABLE OF CONTENTS

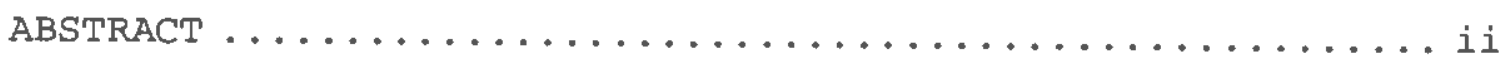

ACKNOWLEDGEMENTS ......................... iv

PREFACE $\ldots \ldots \ldots \ldots \ldots \ldots \ldots \ldots \ldots \ldots \ldots \ldots \ldots \ldots \ldots$

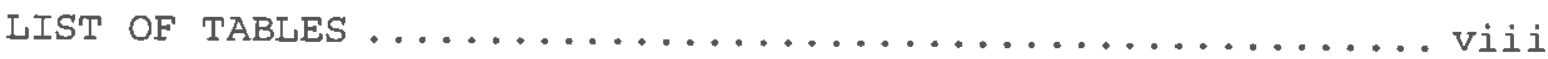

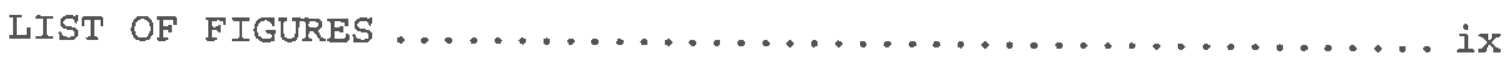

MANUSCRIPT: ARTISTS AND TEXTILE DESIGN:

THE ONONDAGA SILK COMPANY'S "AMERICAN ARTIST PRINT

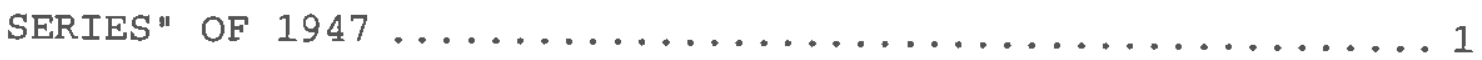

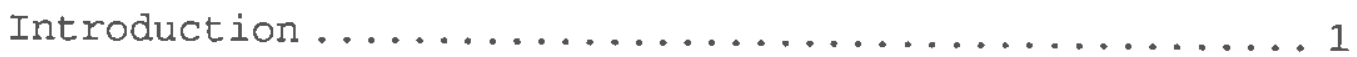

The Onondaga Silk Company's "American Artist

Print series" of $1947 \ldots \ldots \ldots \ldots \ldots \ldots \ldots \ldots \ldots$

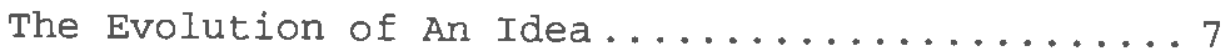

Choosing the Artists and The Paintings........9

The Fabric Prints Are Designed............ 15

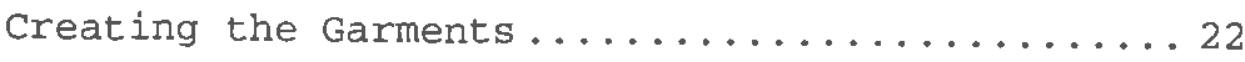

The Presentation and Promotion...............33

Continuing the Idea................... 37

The "American Artist Print Series" in Context......38

Literature cited ......................... 55

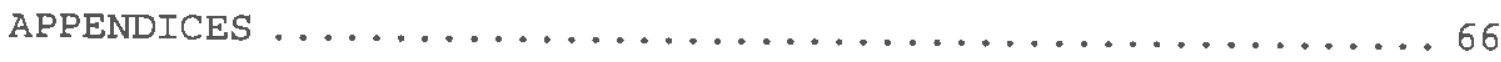

APPENDIX A................................ 67

Design Influences in the Early Twentieth

Century ................................ 67

Fashion Design in the Early Twentieth Century ......72

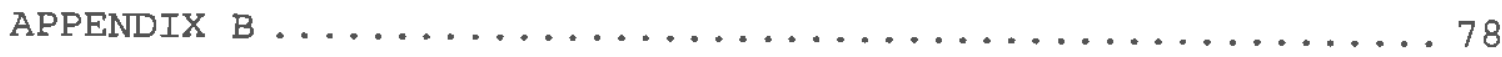


Paintings and Designs Sent to The Onondaga Silk

Company .............................

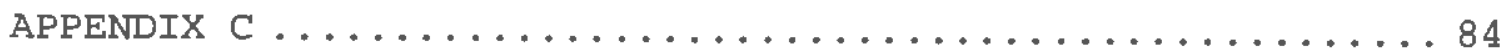

Extant Paintings, Textile Design Samples, and

Garments .............................. 84

APPENDIX D .................................... 85

Biographies of Artists Involved with the

"American Artist Print Series" ................ 85

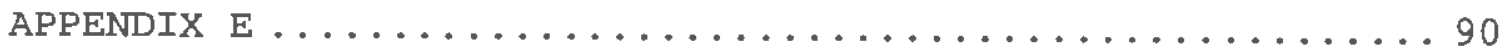

Biographies of Designers Involved with the

American Artist Print Series"................. 90

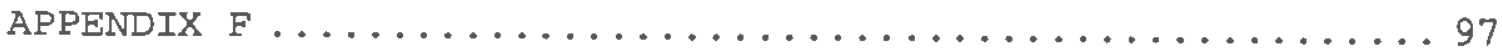

Quantities of Yardage Sold of Fabrics From the

"American Artist Print Series" ................ 97

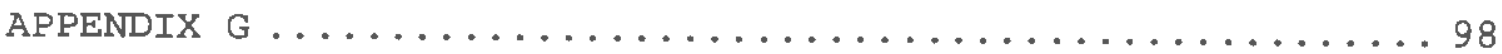

List of Institutions Contacted ..............98

BIBLIOGRAPHY ............................. 101 


\section{LIST OF TABLES}

TABLE 1. The "American Artist Print Series" by the onondaga Silk Co., 1947: Textile Designs and Their Corresponding Painting Titles ............... 12

TABLE 2. Production Schedule for the "American Artist Print

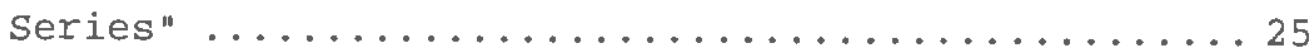

TABLE 3. Onondaga Silk Print Exhibition Schedule....... 34 


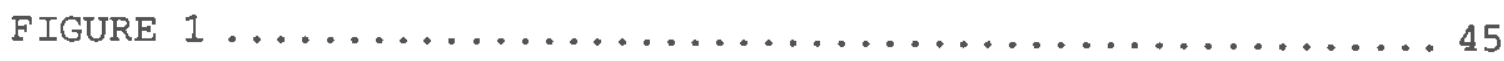

A. "Sun, Water And Air" Painting by william Palmer,

Dress by Emmet Joyce of Samuel Kass, Inc

B. "Sun, water And Air" Textile Design by Onondaga Silk Company

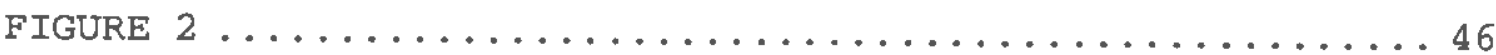

A. "Horses" Painting by william Palmer

B. "Horses and Corrals" Textile Design by Onondaga Silk Company

C. "Horses" Dress by Eta of Ren-Eta

A. "The Dogwood's Last Stand" Painting by Waldo Peirce

B. "Clouds and Trees" Textile by Onondaga Silk Company

C. "Clouds and Trees" Dress by Eta of Ren-Eta

A. "Cider Press" Painting by Waldo Peirce, Evening Dress by Nettie Rosenstein

B. "Cider Press" Afternoon Dress by Nettie Rosenstein

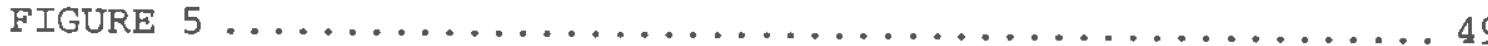

A. "White House" Painting by Dong Kingman

B. "New Orleans" Textile Design by the Onondaga Silk Company

C. "New Orleans" Dress by Jo Copeland of Pattullo 
FIGURE 6 50

A. "Back Yard" Painting by Dong Kingman

B. "Chickens in Squares" Textile Design by the Onondaga Silk Company

C. "Chickens in Squares" Dress by Jo Copeland of Pattullo

A. "Carousel" Painting by Gladys Rockmore Davis

B. "Carousel" Textile Design by the Onondaga Silk Company, Dress by Nettie Rosenstein

FIGURE 8

A. "Corn Foliage" Textile Design by the Onondaga Silk Company

B. "Corn Foliage" Evening Dress by Brownie of Foxbrownie FIGURE 9

A. "Fine Creek Mills" Textile Design by the Onondaga Silk Company

B. "Fine Creek Mills" Afternoon Dress by Brownie of Foxbrownie

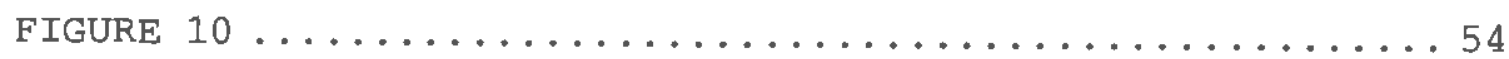

A. "Woman with a Hat" Textile Design by Julien Binford

B. "Woman with a Hat" Dress Design by Bruno of Spectator Sports 
ARTISTS AND TEXTILE DESIGN:

THE ONONDAGA SILK COMPANY'S "AMERICAN ARTIST PRINT SERIES" OF 1947

\section{Introduction}

Most publications on twentieth century textile design and fashion leap from examples of Art Deco to the styles of the mid1950 s and the beginnings of Pop Art. These publications also focus primarily on European design. Currently, scholars are trying to correct the omission of non-European textile and fashion design from design history. They are attempting to show the stylistic, historical, and cultural importance of previously unacknowledged textile designs within industrial design of the twentieth century. Interest is also building concerning the connections between these designs and early twentieth-century social and political issues. 1

Scholars are exploring the previously unknown textile designers behind American firms of the twenties and thirties and studying the designs produced by individual companies, such as the Stehli Silk Company or H.R Mallinson's \& Co. ${ }^{2}$ They are looking at individual textile artists, such as the works of Ruth 
Reeves, and the impact of their contributions to the field of design. ${ }^{3}$ A 1993 exhibit at the Museum of Fine Arts in Boston, Massachusetts recently reconsidered textiles from the Arts and Crafts Movement to the Art Deco period, exhibiting accomplishments of little-known artists Marguerite zorach and Ruth Reeves alongside major manufacturers such as Fortuny, Inc., Liberty and Company, Morris and company, and Cheney Brothers. 4 Yet, even among these studies, the stylistic period between 1945 and 1955 has not been considered. Designs of the postWorld War II era were remarkable because of their popularity and their originality. Many textile designs of this period stand out because of their relationship with fine art. Throughout history, fine artists have created tapestries and embroideries, sketching the designs to be worked out by technicians or creating copperplate and woodblock images for fabric printers.

In the late nineteenth century, a movement to unite art and industry evolved in reaction to the perceived threat to traditional aesthetic values by the bare utilitarianism of new industrial products. The art world attempted to redefine the premise of fine art and make it more accessible to the common person by modifying mass-manufactured products of many kinds. These ideas were reflected in the efforts of William Morris and the Arts and Crafts Movement which encouraged the working relationship between art and industry. The movement left a strong artistic mark on the world of textile design as well as in the design of furniture, wallpapers, glass, and metalwork. In the process of production, artists often combined the ideas 
of different media forms to achieve their aesthetic goals. Many of the designs of the early twentieth century can be traced back to the influences of the works of the artists involved.5

At this same time, the industrial world began to pursue new possibilities for increased production and sales. With the technical advances in production, industry produced large quantities of inexpensive items. Companies spent more time on the designs of their products to compete more strongly in their markets. The industrial designer, an individual whose job it was to interpret and modify technological innovations to appeal to the consumer of mass-manufactured goods and thus increase sales, was born. Often this designer had art training or appealed to an artist for inspiration. Some of the artists who became involved with industry were well known, and their celebrity helped sell the products with which they were associated. More frequently, artists existed under the umbrella of a company name as in-house designers, without public recognition on labels or in promotional materials. 6

The combination of the two worlds, art and industry, allowed for good design to reach a greater percentage of the population than it previously had. As a result, manufactured products began to change. Design emerged as a new and important way to enhance normal, everyday objects and give them special meaning. 7 The consumer also began to determine what became fashionable by what he or she bought.

Painters, sculptors, and architects became involved with other media besides their own as the twentieth century 
developed. Painters Salvador Dali and Georgia O'Keefe, for example, collaborated with steuben glass to create the series "27 Artists in Glass." 8 John Murray, architect and designer, produced roller printed rayons and cottons. ${ }^{9}$

Artists who were familiar with the relatively new graphic art of screen printing on paper began to explore its use with textiles. The textile industry began to actively seek artists to design their products.10 Screen printing began to be used for decorating textiles in the early twenties in Europe and England and in the late thirties and early forties in America.11 Businesses such as Ascher, Ltd. of England, BianchiniFerrier, Edinburgh Weavers, Itd., and Allan Walton depicted contemporary artists' works on their textiles in the years before World War II.12 Some of these textiles were designed by internationally-known artists such as salvador Dali, Vertès, Raoul Dufy, and Fernand Léger, while others were created by artists known only to the companies. ${ }^{13}$ Several of these artists worked for more than one company over the years; Raoul Dufy worked for both Onondaga and Bianchini-Ferrier. ${ }^{14}$ Henri Matisse, Pablo Picasso, Alexander Calder, Angelo Testa, and Henry Moore also are among the better-known artists who explored the medium of textiles.15 Unfortunately, their interest in textiles is usually considered an exception to their role as painters or sculptors and is glossed over in light of their other achievements.

Between the two world wars emphasis turned to increased production, efficiency and economically viable enterprises. 
Governments began to use the arts for the betterment of society. Britain employed artists to design or decorate manufactured objects through the Design and Industries Association in the 1930s. ${ }^{16}$ Another program established in America was the Federal Art Project which started in 1935. This project responded to problematic economic forces by providing American artists with available work. ${ }^{17}$ The industrial designer gained status in every industry. ${ }^{18}$

During World war II, many rollers and printing plates were requisitioned in both England and the United states for their metal content. ${ }^{19}$ The textile industry had to look for other methods and materials for producing printed fabrics. Interest in and growing competence with screen printing as a surface design technique for textiles grew. ${ }^{20}$

The textile designs which emerged from this collaboration between the textile industry, screen printers, and artists featured a common visual style. Screen printing allowed textile printers to produce finer lines with greater control of color which led to more calligraphic results. ${ }^{21}$ This method also allowed for larger pattern repeats because designs were no longer confined to the 18" repeat dictated by the circumference of a roller. ${ }^{22}$

The calligraphic images of early screen printed textiles were often combined with washes of color in the background or as contrasting amorphous shapes reminiscent of other art at this time. This style was often called biomorphic or semiabstract. ${ }^{23}$ Printed textiles from this period are similar to 
painted works by Arshile Gorky, Joan Miró, and mobile artist Alexander Calder, and furniture designer Eero Saarinen. By the end of the war this biomorphic style had become well established, although it was not the only style used.

At the close of the second world war, the center of art and industrial design shifted from Europe to the United States. ${ }^{24}$ Many artists sought refuge from the chaos of Europe or strove to explore the developing art of modern industrial America. ${ }^{25}$ Thus, the stage was set for the collaboration between fine artists and the American textile industry.

This study explores a segment of American textile design in the United states in post-World war II by focussing on artistic dress fabrics produced by the Onondaga silk Company of New York City for the spring of 1947. The inspiration for these fashion fabrics were paintings created by American artists represented by a New York City art gallery.

The Onondaga Silk Company's "American Artist Print Series" is examined from its initial conception, through the choice of painters and paintings, the interpretation of motifs by industrial designers into textile designs, and the creation of garments by leading ready-to-wear designers, to the public presentation and its impact. The relationship between artists and the textile industry is considered in the context of twentieth century design. Primary sources included textile artifacts, garments, and renderings of art which influenced these artifacts, as well as newspapers, periodicals, and business records. 
The goal of this study is to bring attention to textile designs inspired by American artists in the late 1940s. The directors of the Onondaga Silk Company and the Midtown Galleries produced the "American Artist Print Series" in 1947 believing that they were taking a great and unique step into the history of textile design. Until now, this collaboration and others like it have been little known or recognized.

The Onondaga Silk Company's "American Artist Print Series" of 1947

The Evolution of An Idea

In the spring of 1947 the onondaga Silk Company of the United states produced a collection of screen-printed textiles for use in fashionable apparel entitled "American Artist Print Series." The company had worked with artists to design textile prints before 1947, but this was the first time it singled out American artists and took the designs directly from previously painted works as opposed to having the artists create designs especially for textiles.

The Onondaga Silk Company was established in $1918 .{ }^{26}$ In April of 1930 it merged with the old Colony silk Mills of New Bedford, Massachusetts. ${ }^{27}$ At this point it had mills in Syracuse and Ogdensburg, New York, and Easton, Pennsylvania, as well as offices in Chicago and Los Angeles. ${ }^{28}$ The company produced its own fabric from throwing and spinning the raw materials to weaving fabric and printing. It produced plain, 
jacquard, velvet, and printed fabrics of rayon and silk, for use in the manufacture of ties, linings, and fashionable apparel. ${ }^{29}$

The "American Artist Print Series" was a collaboration between Onondaga and the Midtown Galleries of New York City. The idea was the inspiration of the wife of the director of the gallery, Mary Gruskin, who presented it to Onondaga. ${ }^{30}$ Onondaga's president described the goal of the collaboration as:

....not to turn the painter into a textile designer, but rather to make intelligent and expert use for fashion of the motifs, coloring and style expressed by his special talents.... To catch the spirit of the fine painter's work on fabric....'31

He and others thought that this project was highly original and "one of the most unusual and exciting ventures ever undertaken in American Art or in American Fashions." 32

Both the silk company and the gallery must have considered the commercial aspect of this venture. The textiles had to appeal to the aesthetic nature of consumers and their fascination with art to assure fabric sales. The finished garments had to conform to current trends in fashion. Thus, the concept had to consider both the conservatism of the public after the war and the consumer's interest in novelty and change. When completed, the paintings, textile designs and garments made with the textile prints were brought together for an exhibition which toured several major cities in the united States. 
Choosing the Artists and The Paintings

The group of six American artists chosen by Onondaga -William Palmer, Waldo Peirce, Dong Kingman, Gladys Rockmore Davis, Doris Rosenthal, and Julien Binford -- were exhibiting their works at the Midtown Galleries in New York City in 1946. These artists worked in the mediums of oils, watercolors and pastels. Each artist had his or her own style and favorite subject, and the textile designs produced from their paintings reflected their individuality. None of these artists could be termed avant garde. Their paintings did not reflect the abstract expressionism of Jackson Pollack or Kandinsky or the surrealism of Salvador Dali. Instead they were reminiscent of traditional, literal painters and American scene realists which included Edward Hopper, Grant wood, and Andrew Wyeth. ${ }^{33}$

William Palmer devoted himself primarily to painting and murals which portrayed landscapes and scenery of New York State. ${ }^{34}$ waldo Pierce produced impressionistic landscapes and still lifes in oils and watercolors. ${ }^{35}$ Dong kingman worked with watercolors as a painter, illustrator and muralist. ${ }^{36} \mathrm{His}$ subjects included city scenes and city objects. Gladys Rockmore Davis worked in the medium of pastels to portray theatrical imagery, ${ }^{37}$ Doris Rosenthal was known for her painting, as well as her work in 1ithography, which focussed on Central American themes and images. ${ }^{38}$ Julien Binford concentrated on images local to his hometown in Virginia using watercolors and oils. ${ }^{39}$ Notes in the Archives of American Art record the selection process of the paintings and sketches used for the printed 
textiles: the images were "made for the purpose or taken from previous work...," and the selection was "to recreate on silk themes frequently used in the artist's paintings."40 In March of 1946, Midtown Galleries sent Onondaga five paintings by Rosenthal on the twenty-first, and another seven paintings by Palmer on the twenty-fifth. On April 3, 1946, seventeen more paintings were sent: three by Binford, three by Palmer, three by Kingman, three by Rosenthal, three by Peirce, and two from Davis.

The artists were given $\$ 150$ advance royalties for each design. Up to this point, none of the paintings or designs were specifically titled in the archival records. Finally a more complete list of titles selected for onondaga by Midtown, dated April 10, 1946, appeared as follows ${ }^{41}$ :

$\begin{array}{ll}\text { Davis } & \text { "Carousel" } \\ & \text { "Giselle" } \\ & \text { "Ballet Slippers" } \\ \text { Peirce } & \text { "Trout Fishing" } \\ & \text { "Cider Press" } \\ & \text { "The Catch (Fish in Net)" } \\ & \text { "Rittens at Play" } \\ & \text { "Jardin Aux Lilas" } \\ \text { Kingman } & \text { "Red Poppy" } \\ & \text { "Chickens" } \\ & \text { "Trew Orleans" } \\ \text { Rosenthal } & \text { "Guatemalan Water Carriers" } \\ & \text { "Papaya" } \\ & \text { "Tropical Foliage" } \\ & \text { Tropical Fruit" } \\ \text { "Summer Pleasures" } & \text { "Fish Reels" } \\ \text { Palmer } & \text { Horses" }\end{array}$




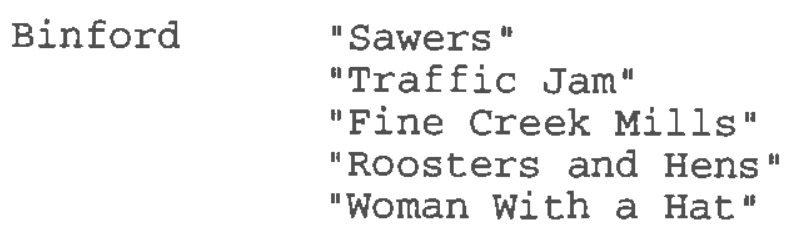

Some of the designs included in the final series are in this list. A few eventually would be excluded, and others added before the textiles were produced, but the selection had almost been completed as comparison to Table 1 shows. Although records are haphazard, a fairly accurate account of the selection process can be reconstructed. By June 20, 1946, eight more paintings by Davis (1), Kingman (2), and Peirce (5) were selected, although the titles are unknown. Again the artists were given $\$ 150$ advance royalties for each design. ${ }^{42}$

The final selection included two works by william Palmer, "Sun, Water and Air" and "Horses," which exhibit the subjective expressionism often evident in American Scene painting (Figures $1 \mathrm{~A}$ and $2 \mathrm{~A}) .{ }^{43}$ In each, the focus is concentrated with intensity on the subjects by the use of light and line. The subjects are dwarfed by the surrounding elements and time seems frozen.

Waldo Peirce's works in this series also have a strong ethereal quality of American Scene painting, but his style is impressionistic. ${ }^{44}$ He concentrated on image and color rather than on linear detail. His paintings for this collection range from sweeping landscapes and allegorical subjects such as "The Dogwood's Last Stand" (Figure 3A) and "Europa and the Bull" to 
TABLE 1

THE "AMERICAN ARTIST PRINT SERIES" BY THE ONONDAGA SILK CO., 1947: TEXTILE DESIGNS AND THEIR CORRESPONDING PAINTING TITLES 45

Artist (total \# of textiles created from paintings) Textile title painting title, medium

William Palmer (3)
Horses and Corrals
Sun, Water and Air
Horses
Waldo peirce (7)
Jardin Aux Lilas
Kittens at Play
Fish in Net
Trout Fishing
Sea Fantasy
Clouds and Trees, Trees
Cider Press, or Down East

Dong Kingman (4)

New Orleans

Trees

Red Poppy

Chickens in Squares

Gladvs Rockmore Davis (3)

Ballet Slippers

Carousel

Giselle

Doris Rosenthal (3)

Corn Foliage

Papayas 47

Papayas

Julien Binford (3)

White Chickens

Fine Creek Mills, or The

Farmer's Daughter

woman with a Hat
Horses, watercolor

Sun, Water and Air

Horses, watercolor

Lilac Garden

Autumn Leaves with Kittens

The catch, or Fish in

Net, watercolor

Trout Fishing, watercolor

Europa and The Bull, oil

The Dogwood's Last stand, oil

on the Penobscot, or Cider Press, oil

White House, watercolor Trees, watercolor

Red Poppy, watercolor

Back Yard[s] ${ }^{46}$, watercolor

Ballet slippers, oil

Carousel \#1, oil

Giselle, oil

Children and Corn, pastel

Papaya, or Flowers and Fruit, Fruit on Table, pastel

Rooster(s) in the Coal Bin, oil Scythe Sharpener of Fine

Creek Mills, watercolor

Woman with (a) Hat, watercolor 
more specific scenes such as "Jardin Aux Lilas," "Autumn Leaves and Kittens," and "The Catch." His choice of subject in "Europa and the Bull" also shows the neoclassical influence on design that arrived during the 1930s and 1940s with Art Deco from Italy. ${ }^{4 B}$ Peirce's "Trout Fishing," and "Cider Press/ on the Penobscot" follow the regionalist school of American Scene painting (Figure 4A). ${ }^{49}$ These images came from his native state of Maine.

In contrast to the works of Palmer and Peirce, Dong Kingman's paintings evoke a sense of dynamism and immediacy. His paintings, "Trees," "White House," and "Back Yards" epitomize this feeling (Figure 5A and 6A).50 They are vivid interpretations of everyday scenes which emphasize the images and focus less on underlying themes. Kingman's style can be compared to that of other regionalists through his choices of subject matter; but unlike the regionalists, he did not limit himself to American scenes. He chose his subjects from his environment by walking around until he found an image that fascinated him. This environment could be San Francisco, New York, Bangkok or New Orleans. 51

Gladys Rockmore Davis' themes were often mythical, idealistic, and romantic. Her subjects consisted of images derived from the theater and children's stories which she frequently illustrated. ${ }^{52}$ The label copy accompanying the Onondaga textile exhibition mentioned that Davis "prefers to paint easily recognizable figures."53 Perhaps this is what drew her to representational images for "Ballet slippers" and 
"Carousel" (Figure 7A). The former depicts the backstage scene of preparing for a ballet while the latter shows a simple outdoor park scene. ${ }^{4}$ She later submitted similar designs to Onondaga for another series produced in 1949.55

Doris Rosenthal painted primarily tropical subjects. Her work showed a preoccupation with Central America, specifically Mexico and Guatemala. Two Guggenheim fellowships in Mexico in the early and mid-1930s may have led to or supported this fascination. ${ }^{56}$ Even Rosenthal's less obvious subject in "Children and Corn" seems to have originated from a sketch from Guatemala. 57

Julien Binford is less well known than the other painters. Little has been written on his life or his work, but his interests can be discovered by examining the titles of the works he submitted to Onondaga before and after this series was produced. He followed the path of the regionalists and worked primarily with genre which included many rural scenes of his local Virginia landscapes. These scenes often focussed on farming activities. 58

The final selection of paintings followed traditional artistic styles from the thirties, primarily regionalism and American scene painting, rather than the newer avant garde trends of surrealism or abstract expressionism. The use of detail and line in these American styles contain traces of transcendentalism and literal puritanism where European painting styles usually reflect classicism and romanticism. ${ }^{59}$ Although the works chosen by the onondaga silk company and the Midtown 
Galleries for this series may not have been on the cutting edge of contemporary artistic style as were the works of Pollack, de Kooning, Miró, or Gorky, they were good examples of the more traditional style of American painting of this time period.

The Fabric Prints Are Designed

After the final selection, Onondaga's industrial designers translated the paintings into suitable designs for dress fabrics. The original images by the artists were intended for rigid, static paintings rather than for three-dimensional, flexible flowing forms. ${ }^{60}$ Draping, cutting, and sewing printed fabrics into garments can either create a successful fashion design or completely ruin the graphic image on the material. Thus, the industrial designers had to adapt the paintings into textile designs appropriate for use by dressmakers.

The industrial designers did not confine themselves to literal interpretations of the paintings but often chose sections or specific motifs for their adaptations. They tried to stay as true to the original character and style of the paintings as possible, but occasionally modified the motifs. ${ }^{61}$

In this series, the interpretation of William Palmer's painting "Sun, Water and Air" appears on a white silk crepe with a fine black outline of hills and trees accented with yellow and pink splashes of color.62 The label copy noted, "the elements were skillfully simplified" during their translation, yet the dramatic intensity of the painting is still apparent. The scene was translated into alternating oblique repeats which measure 
15" high by $201 / 2$ "wide (Figures $1 \mathrm{~A}$ and 1B).63 This arrangement of the repeats leaves little open space, making the pattern more visually interesting than if each scene were lined up horizontally.

Palmer's other painting, "Horses," was ultimately translated into two different designs for the textiles. In each, the horses are different shades than the original painting, one also was modified with spots. Riders also were added to the scene in each interpretation, and the theme of one pattern was adapted to the old west.

The first interpretation, "Horses and Corrals," was a very linear, horizontal representation with pairs of horses running across the width of the material. The emphasis is on the whole panorama, and the scenery includes cacti and linear corral fencing which the original painting does not contain. The design consists of three scenes, horses galloping in pairs, empty corrals, and lone riders in a desert in a horizontal and vertical repeat of $81 / 4 "$ in each direction. This design appeared in combinations of blue washes of color on a white silk crepe and in red washes on white rayon crepe. ${ }^{64}$

The other textile design, "Horses," more closely mirrored the image from the painting. It focussed on the foreground figures of the horses and interpreted the scenery in an abstract manner. The motion and impressionistic style of the painting is carried by the curvilenear shape of the textile design. The balance of the active foreground and the inactive background of the painting is carried over to the textile design through the 
intermittent spacing of the compact design on the plain background. The circular design also returns the eye to the motifs and away from the overall effect the pattern repeats. This large design was repeated in green and black on silk (Figures $2 \mathrm{~B}$ and $2 \mathrm{C}$ ). 65

Waldo Peirce's "Europa and the Bull" also was modified for the fabric print, this time to allow for social sensibilities, and retitled "Sea Fantasy." The final design depicts a 16" high by 17" wide repeat of a green- and yellow-clothed Grecian nymph in the place of the nude Europa seated on the back of a gray and black bull on a gray silk crepe. ${ }^{66}$

The exhibit label for "Trout Fishing" states "by giving stronger accents to some tree and rock forms and by more closely interlacing the foliage a well knit all-over design has been achieved." 67 The pattern abounds with activity through the use of many small curved lines and unichrome accents. The focus is the image of a fisherman casting his rod into a stream in alternating directions. Unfortunately, it is difficult to find him amidst the overall pattern of trees and rocks. The design appears in shades of brown, red, or green washed over a black. outline in a half-drop repeat $143 / 4$ " high by $141 / 2$ " wide on white rayon or silk crepe. The brown colorway is similar to the artist's original work. ${ }^{68}$

Similarly, Peirce's "Cider Press" is adapted into a very active design. Yet, the polychrome nature of the print defines the images and the whole scene more clearly. The print appeared in washes of green, red, blue and yellow on a white silk crepe 
with the main images highlighted with black.69 Furthermore, "a clever use of red accents and Peirce's sprightly brushstroke give the necessary decorative quality. "70

The industrial designers also managed to carry over the impressionism of the painting "The Dogwood's Last Stand" into the textile "Clouds and Trees" (Figures $3 \mathrm{~A}$ and $3 \mathrm{~B}$ ). It portrays the idea of the fall scene by emphasizing the darkened tree trunks and using washes of bright color for the areas of leaves

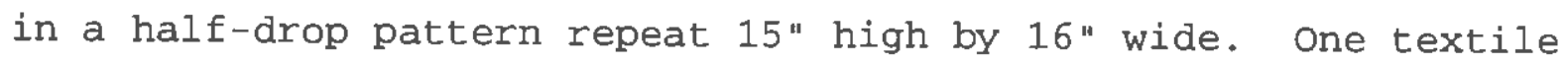
is described as blue, green and gold, while another example was yellow, tan, and brown on white silk crepe. ${ }^{71}$

The designers were intrigued by kingman's work, perhaps because of its graphic qualities. The label accompanying "Red Poppies" states "In Dong Kingman the fabric industry has uncovered a highly skilful[sic] designer - if he could be tempted away from his own highly creative way of painting."72 This was not likely to happen. As much as they liked Kingman's works, they interpreted them less directly and more thematically by choosing selected motifs for repeated prints. In this instance the industrial designers also did not follow Kingman's suggestion of colors, which was for a red and yellow print, but instead used black and red on gray and white silk crepe.73

This selected choice of motifs by the industrial designers is clearly evident in the description of their work with "Back Yard[s]" and "White House." "New Orleans" was a successful adaptation of "White House" although it does not exactly mirror its origin: 


\begin{abstract}
Here...these motifs were 'lifted' from Dong Kingman's colorful watercolor of an old New Orleans street corner, re-arranged by the industrial designer into an all-over, closely packed pattern and then printed by the manufacturer with nice attention to color (Figures $5 \mathrm{~A}$ and $5 \mathrm{~B}) .74$
\end{abstract}

The resulting fabric was a polychrome silk crepe using the images of the car, street lamp, posts, and fence interspersed with trees and a doorway in alternating horizontal rows which created a vibrant urban scene for a 15 " high by $101 / 2$ " wide pattern repeat. ${ }^{75}$

Meanwhile, only a small portion of "Back Yards" was used for "Chickens in Squares" as the label states:

This print, above all others in the exhibition, shows the important role of the industrial artist in re-working the artist's original idea into a workable, printable pattern. Not only was the drawing of one chicken enlarged and made more decorative, but the design was reversed in alternative rows to give variety and prevent a monotonous effect (Figures $6 \mathrm{~A}$ and $6 \mathrm{~B}$ ). .76

The painting shows the chickens in the lower left hand corner as a small part of the main back yard scenery. The chickens become the focus of the textile print, alternating in a checkerboard pattern with two-colored squares in a repeat $63 / 4 "$ high by 6 3/4" wide. This is the smallest pattern repeat used in this selection of prints. The colors of this design are red, blue, and yellow print on white rayon crepe. 77

The industrial designers appreciated the larger scaled motifs for their translations. ${ }^{78}$ Among these were Davis' works 
"Carousel," and "Ballet slippers" (Figures 7A and 7B).

"Carouse1" is almost an exact reproduction of Davis' painting minus the children in the foreground. The printed polychrome design was $201 / 4 "$ high by $30^{\prime \prime}$ wide on silk crepe. The example studied did not have a full repeat, but it was noted that the design was printed in four rotations around the top of the image. ${ }^{79}$ "Ballet slippers" displays the images of ballerinas, crowns of roses, pairs of slippers, and pointed hats directly from Davis' painting in blue, pink, yellow, black, and white discharge on the $41 "$ wide silk crepe. 80

The example of the textile design "Papayas," originating from either Doris Rosenthal's "Fruit on Table, " is similar to the adaptation of Davis" "Ballet slippers." It is quite large without a full repeat over the 23" high by $20 "$ wide area of the silk crepe example. The motifs are of pineapples, papayas, and leaves. ${ }^{81}$ Another print of this title but which depicted branches of banana trees was derived from "Flowers and Fruit." 82 "Corn Foliage", on the other hand, repeats the vertically oriented stalks of corn in a half-drop repeat 15" high by 17 $1 / 2 "$ wide (Figure $8 \mathrm{~A}$ ). The images in this design are outlined in fine black lines with evenly balanced highlights of color. ${ }^{83}$ Unfortunately, since the origin of this design has not been located to date, the process of transformation from the original painting to textile is not known.

The designs derived from Julien Binford's paintings consisted of two rural farm scenes, one of chickens being fed near a coal bin and the other of general farming and harvesting 
activities. The first scene was almost directly reproduced onto fabric effectively using the figure of a farmer to connect the multidirectional images of the hens and roosters. The print appears in a $91 / 2$ " wide by $131 / 4$ " repeat on both gray and blue silk and rayon crepe. ${ }^{84}$

A description of the latter scene, "Fine Creek Mills," stated that "the fabric retains much of the spirited brush-work and drawing quality that Binford achieved in his first drawing" (Figure 9A). ${ }^{85}$ The completed design is a half-drop repeat 14 3/4" high by 15" wide. Examples of this print exist in red and gray on white rayon crepe and in gold and gray on white silk crepe. ${ }^{86}$

Binford's "Woman with a Hat" was deened "one of the most successful carry-over patterns from paintings to fabric designs in the exhibition" (Figure 10A). ${ }^{87}$ This design is ambiguous with the multi-directional repeated pattern of the body of a tiny, thin woman under an oversized hat. The variation of the motif in size and orientation keeps the eye from lingering on any one aspect of the design. The circular hat also is countered by the linear nature of the woman's body and limbs. Although the motif in this print is small the design repeat is $141 / 2 "$ high by $93 / 4$ " wide. The black design was used on both green and a bright pink silk crepe. ${ }^{88}$

Many of the textile designs produced through this collaboration of painters and industrial designers exhibit a combination of fine calligraphic lines and washes of color which are characteristic of textile prints produced in the late 
forties, including those by Ascher, Ltd. and Bianchini-Ferrier. The finished prints also parallel the styles of abstract expressionist art gaining in popularity after 1945 such as that by Arshile Gorky, Joan Miró, Willem de kooning and others. The designs combined the traditional styles of the original paintings with contemporary textile design trends.

\section{Creating the Garments}

The next stage was for garments to be made from the printed fabrics. The style of a garment contributes as much to its success as the design of the textile used. The overall silhouette is as important as detail. When used in different manners, the overall shape and line can make a garment appear sporty or elegant. It can disguise some parts of body or emphasize others. ${ }^{89}$

To make a successful garment, the print design should not overwhelm the shape, nor should the shape overwhelm the print design. Each should be set off by the other in a complementary balance. The fashion designers had to keep in mind the large scale of some of the textile prints in this series. ${ }^{90}$

Texture and weight of fabric also are important as they influence a designer's method for shaping and cutting a garment. Most of these designers used draping to create their designs. The fabrics in this collection were lightweight silk and rayon crepes. Crepes contribute texture and body which printed silk or rayon fabrics do not always have. ${ }^{91}$ 
styles had remained in stasis during the second world War without many innovations. Common features were well-defined padded shoulders, natural waistlines, and knee-length hems. The stark, square shoulders and defined waist created a trim look similar to that of military uniforms. ${ }^{92}$ Draped or shirred fabric treatments, which had appeared in the late thirties, became more prominent in the forties. The rationing of fabric due to war restrictions was partially the cause of widespread use of these economical ways of making spare designs interesting without using excess fabric. ${ }^{93}$ This was to remain so even after the war ended, although a desire for new designs was in the air. Bright colors fashionable in the late thirties were toned down by the mid forties. Garments appeared with softer lines and fuller skirts as the years progressed. Designers offered variations on the successful designs of the early war years but also tried new ideas with different focal points for less severe silhouettes. 94

The United states had grown strong in the fashion world during the war years. U.S. apparel manufacturers had an available workforce which was less directly affected by the ravages of the war than its European counterparts. 95 The ready-to-wear industry, to which it devoted most of its energy, also gained status as an affordable, fashionable alternative to custom-made clothing. Among the fashion leaders in this industry were Claire McCardell, vera Maxwell, Claire Potter, and Elizabeth Hawes. ${ }^{96}$ 
In July of 1946, the Onondaga Silk Company began fabric production so that garments could be constructed, photographed, and ready for showing by october and November for the previews of the spring fashions. For this stage of production, onondaga sought the talents of some of the most fashionable contemporary American ready-to-wear garment designers who worked alongside those already mentioned: Eta of Ren-Eta, Jo Copeland of Pattullo, Brownie of Foxbrownie, Joset walker of David M. Goodstein, Inc., Sally Milgrim, Morris Kraus of Zuckerman and Kraus, Ben Reig, Bruno of Spectator Sports, Anna Miller, Nettie Rosenstein, Sophie of Saks, and Emmet Joyce of Samuel Kass, Inc. ${ }^{97}$ Their designs were anticipated to arrive at the retailers by January of 1947 (Table 2).

Mme. Eta designed garments for thematic series, such as a Cape cod series and a Grecian series, in the early forties.98 Jo Copeland was raised in the fashion world, her father having worked in the clothing business; she had worked with other Onondaga fabrics before this series. 99 Miss Brownie was well known for designing afternoon and evening garments. 100 Joset Walker designed casual wear and sports clothes.101 Sally Milgrim worked in ready-to-wear as well as custom clothing which included several inaugural gowns for the wives of presidents Harding, Coolidge, and Roosevelt.102 Morris Kraus worked with Ben Zuckerman, another popular designer of this period, designing coats and suits.103 Ben Reig also specialized in coat and suit designs for everyday wear. ${ }^{104}$ Bruno of Spectator Sports ranked among the top designers of the 1940s.105 Anna Miller 
TABLE 2

PRODUCTION SCHEDULE FOR THE "AMERICAN ARTIST PRINT SERIES" 106

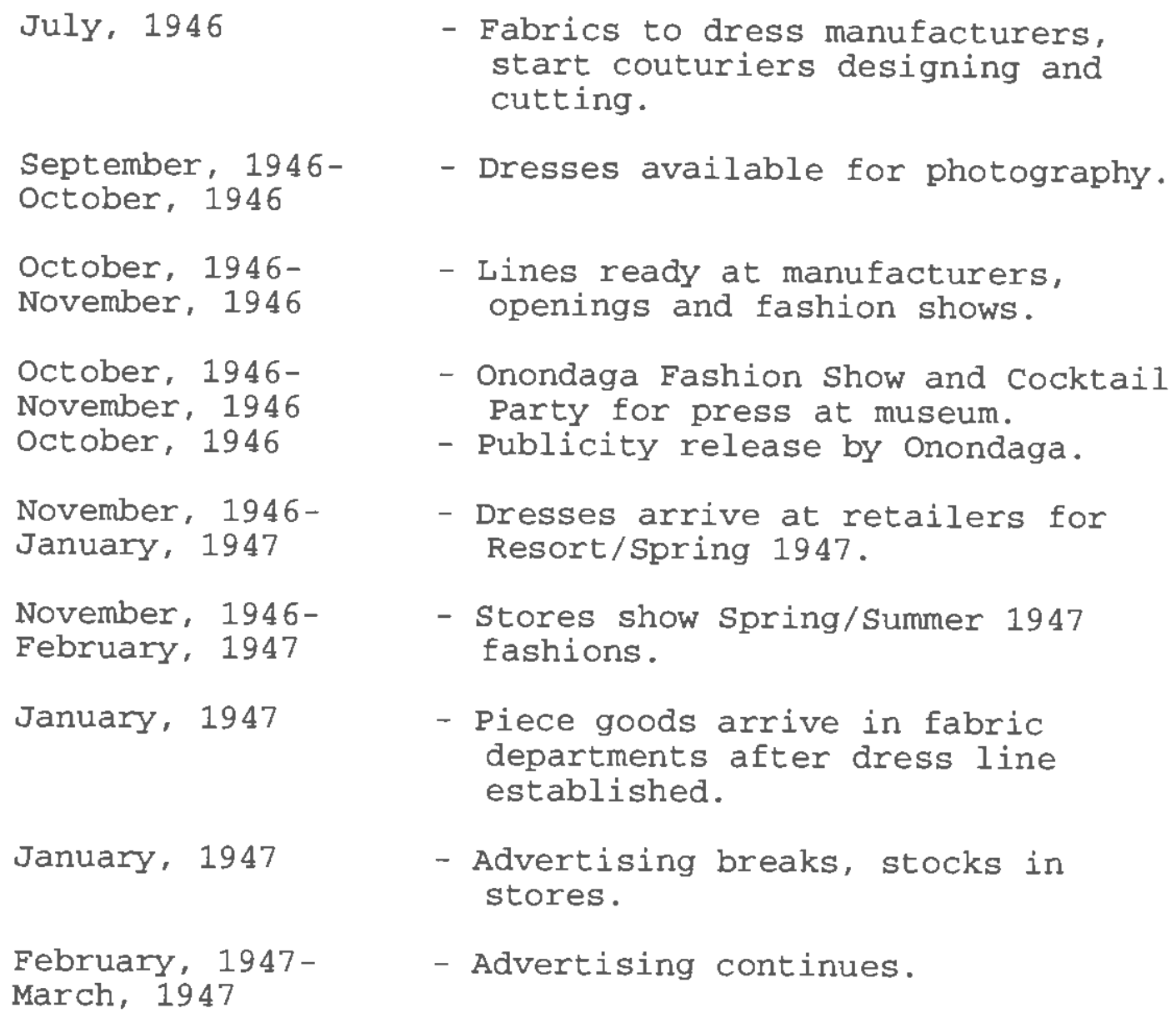
start couturiers designing and cutting.

September, $1946-$ October, 1946

October, $1946-$ November, 1946

October, 1946November, 1946 October, 1946

November, 1946January, 1947

November, 1946-

February, 1947

January, 1947

January, 1947

February, $1947-$ March, 1947

- Dresses available for photography.

- Lines ready at manufacturers, openings and fashion shows.

- Onondaga Fashion Show and Cocktail Party for press at museum.

- Publicity release by Onondaga.

- Dresses arrive at retailers for Resort/Spring 1947.

- Stores show Spring/Summer 1947 fashions.

- Piece goods arrive in fabric departments after dress line established.

- Advertising breaks, stocks in stores.

- Advertising continues. 
designed both for her own business and with her brother Maurice Rentner in the 1960s. ${ }^{107}$ Like Jo Copeland, Nettie Rosenstein had also worked with onondaga on other projects. She was honored in her field by several design awards.108 Sophie of saks designed both made-to-order and ready-to-wear garments, working with Emmet Joyce to produce a "Saks Originals" collection.109 Joyce also designed day and evening dresses of his own.110

Several of the garment designs produced for onondaga's "American Artist Print series" reflected the budding interest in a new softer silhouette. The fabrics were made into daydresses, blouses, dinner and evening dresses, and scarves.111

Emmet Joyce of Samuel Kass, Inc. created an evening dress with William Palmer's textile design "Sun, Water, and Air" which shows the open neckline that began to appear in the late thirties (Figure 1A).112 The dress had a softer look than the earlier forties. The long, simply draped dress was a good vehicle for the elaborate landscape design of the print.

Palmer's "Horses and Corrals" was used in a sport dress by Foxbrownie emphasizing the horizontal arrangement of one of the prints (Figure 2B). Sophie of Saks Fifth Avenue created a fullskirted evening dress with the print "Horses, "which had a circular arrangement of motifs (Figure 2C).113 The evening dress had a sweetheart neckline and fitted bodice, along with a wide, full skirt trimmed with net along the hem.114 Although the sweetheart neckline is characteristic of wartime fashion, the feminine silhouette and full skirt foreshadow Dior's "New Look." The large but closed, curving printed design is well 
complemented by the restrained tailoring and large quantity of material. The outfit is completed with a pair of long black gloves.

Sophie of Saks created a slim evening dress with Peirce's "Jardin Aux Lilas" print.115 The shoulders are gathered towards the side of the bustline, and the sides of the bodice are gathered at the center front. The dress has short cap sleeves. The waist is slim and falls into a straight skirt. A small gathering of fabric at the back softens the straight line. The emphasis on the upper bodice through minimal fabric and busy construction is complemented by the quantity of fabric used in the skirt with minimal construction. The large curvilinear print is used well to balance the simple silhouette. The print shape softens the vertical emphasis of the garment along with the natural curves of the body.

Eta of Ren-Eta worked with waldo Peirce's "Clouds and Trees" to produce a slim evening dress with a gathered halter neckline (Figure 3C). ${ }^{116}$ The bodice shows a draped design reminiscent of the late thirties rather than the squarer, sharper appearance of the forties which leads the eye up to the shoulders and head instead of down to the waist. The draped skirt, gathered to the waist, was reminiscent of the mid-forties creations by Paris designers such as Lucien LeLong and Marcel Rochas. 117 The textile print adapts well to the vertical lines of the dress while also complementing the rounded silhouette. The shape of the dress and the colors of the print are accented along the draped hem by a solid-colored crepe. 
Nettie Rosenstein created two different dresses with the print from Peirce's "Cider Press." Rosenstein designed an evening dress with a soft, bertha collar and draped sleeves (Figure 4A). ${ }^{118}$ The shape of the dress generally follows the body line but does not accent any particular point. It emphasizes the bust and neckline and competes with the busy nature of the design. The silhouette of this dress is similar to the dress from Pierce's "Trout Fishing" but the latter emphasizes the horizontal lines more strongly to contrast accordion pleats in the collar and skirt tiers. 119

The afternoon dress created by Rosenstein, on the other hand, is similar to Eta's adaptation of "Clouds and Trees" with its emphasis on a gathered bustline and fitted waist. ${ }^{120}$ The shoulders are obviously still padded (Figure 4B). This use of structural design balances the busy textile print and allows for the eye to rest briefly from the active rhythm of the whole garment. This dress is accompanied by gloves made of the same textile print.

A good example of the fashion of the day can be seen in Jo Copeland's use of the fabric based on Dong Kingman's painting "New Orleans."121 Copeland manages to soften the square neckline by draping the shoulder area. The natural waistline separates the bodice from the slim single-pleat skirt. (Figure 5C). The acute angle of the pleat emphasizes the small waist while softening the skirt line at the hem. The sharp angle also counters the upward focus of the open neckline. Copeland's 
design balances simple construction with complex print design in a pleasing manner.

Copeland designed a similar style dress from Kingman's "Chickens in Squares."122 This dress works well with the geometric nature of the textile design. The draped neckline offsets the more obvious squares of the print design. The silhouette is softened by draping at the hipline to complement (Figure 6C). The emphasis on the hipline in this dress is leading towards later styles of the forties by Christian Dior. This simple dress design also is made more complex by the diagonal line of the print rather than through construction.

The textile print of Kingman's "Red Poppies" was made into an attractive blouse by Morris Kraus. ${ }^{123}$ This garment design is loose fitting with simple lines. The loose fit softens the square padded shoulders. The busy textile print also provides dimension with its curling, swirling lines and repeating flowers. The blouse would accent a slim suit in color and silhouette.

The print from Gladys Rockmore Davis' "Ballet Slippers" was interpreted in a simply constructed dress. ${ }^{124}$ The clean lines of the dress act as an effective background for the large print in the same way that the black ground of the print is an effective foil for the bright colors of the motifs. The bodice and sleeves are loose but gathered to a fitted waist. The skirt drapes smoothly from the natural waistline. This overall silhouette became very popular in the year to come. 
Davis" "Carousel" presented a challenge for Nettie Rosenstein because of the scale of the design (Figure 7B). Rosenstein managed to utilize it in a suit and blouse combination. The textile design softens the jacket shape and emphasizes the blouse effectively while the dark Coor of the suit acts as a foil for the colorful print. The line of the shoulders and neckline are broadened by the shape of the lapels and emphasized by the colorful print. At the same time, the focus is drawn away from the angular construction of the jacket by the teardrop shapes within the image of the print. Matching dark gloves and a hat complete the suit by maintaining the central focus of the eye on the bodice rather than drawing away from it.

The flowing textile design of Rosenthal's "Corn Foliage" was well suited to the silhouette of the long evening dress designed by Brownie of Foxbrownie (Figure 8B). The shoulder line is broad and square with long, tight fitting sleeves and a high, closed collar. The skirt is essentially a straight sheath with the simple addition of gathering at one hip, emphasizing the natural waistline. This detail also manages to round out the hipline by drawing attention to the waist area. According to principles of good design, this print appears to overpower the simple cut of the dress..

The print "Papayas" from Rosenthal's "Flowers and Fruit" was made into a stunning evening dress using the print to highlight the construction and the silhouette. ${ }^{125}$ The short sleeves are draped from a padded shoulder. The silhouette of 
the dress follows the natural bodyline while the construction of the garment emphasizes the shoulderline and the waist. Meanwhile the print pattern emphasizes the shoulders and the lower skirt and deemphasizes the construction. Each point of the design plays off another to create an overall harmony.

"White Chickens" was used in two different dress designs.126 Joset walker added neutral colored fabric along the sides of the bodice from shoulders to gathered waist, and as a tie at the natural waistline. The skirt drapes smoothly from the gathered waist. The linear, vertical lines and overall silhouette balance the curved shapes and lines created by the multidirectional orientations of the motifs in the print.

This print also was used in a day dress which had a square open neckline and rounded shoulders. A softly draped skirt falls from the natural waistline, emphasized by a cinched belt. Again, the simple lines of the dress offset the busy pattern of the print.

The ensemble designed by Foxbrownie from Binford's painting "Fine Creek Mills" accents the padded shoulder line and natural drape of the skirt (Figure 9B). ${ }^{127}$ The dress is set off by a wide shouldered, loose-fitting, coordinated jacket. The curved hem of the jacket complements its boxy line and the straight hemline of the skirt, displaying the emerging softer ideal. The flared hem of the jacket sleeve balances the fitted print gloves.

Bruno of spectator sports designed a full-waisted dress in from Binford's "Woman with a Hat" (Figure 9B). ${ }^{28}$ The full skirt 
required more fabric than some of the other designs and showed the declining interest in conservative styles of the early forties. The natural waistline and the padded shoulders weight the dress on a horizontal plane, but the high collar and the gathers of the skirt balance the garment on the vertical plane. The loose construction of the draped cap sleeves and soft lines of the skirt also lessen the vertical line. Matching gloves provide a linear balance for the rounded shape of the waist. This balance, shape, and line is carried over well into the dress design from the textile print.

The success of these garments depended strongly on their appeal to the public who were accepting of some conservative styling while also looking for something new. The resulting garments reflected the influences of design and the changing American culture on the fashion of the post-war period.

The hard-edged silhouettes of the pre-war era were still produced by top designers for the contemporary market, but these designers were experimenting with draping and gathering to produce softer looks. To do this they emphasized shoulders, necklines, waists, hips, and hemlines. Designs were considered successful if they balanced these details well while also utilizing the patterns of the fabrics.

Ultimately, the presentation and sales to the consumer would determine the success or failure of the textile designs, their interpretations, and the garments themselves. The garments made with these onondaga prints were carried by leading 
department stores in the United states and advertised alongside those of current European designers.129

The Presentation and Promotion

Onondaga presented their printed designs as a complete package, paintings into garments, on the afternoon of December 16, 1946 in the Ritz Carlton Ballroom in New York City. The exhibition included the paintings, yard samples of the fabric prints, and the finished garments. A color film also was made to record the creative process behind the production and to be shown along with the exhibition. ${ }^{130}$ Invitations were sent to newspapers, radio stations, and magazines. ${ }^{131}$

After its presentation, the garments were to arrive at retailers by January 1947, and the fabrics were to become available as piece goods soon after. ${ }^{132}$ At the same time, the show traveled to several major cities and department store chains such as the R.H. Sterns Company in Boston, Massachusetts; Rich's, Inc, in Atlanta, Georgia; and Bloomingdale's in New York in promotion of the fabrics. ${ }^{133}$ Bloomingdale's produced an advertising catalog for promotion of the dresses. ${ }^{134}$ The exhibition was also requested by art museums and design schools (Table 3). Several letters responding to requests for the show mention a $\$ 50$ fee, not including shipping and handling charges for the use of the exhibit. 135

As for the success of the fabrics and dresses, the royalty figures indicate that the prints varied in sales, but whether this was due to the subject matter, their translation into 
TABLE 3

ONONDAGA SILK PRINTS EXHIBITION SCHEDULE 136

Jan. 1947

Feb. 1947

March 1947

April 1947

May 25, 1947June 9, 1947

June 22, 1947July 31, 1947

Sept. 1-19, 1947

Oct. 1-22, 1947

Nov. 2-30, 1947 Munson-Williams-Proctor Institute Utica N.Y.

Dec. 8-31, 1947 Springfield Museum of Art Springfield, Missouri

Jan. 12-31,1948 Fort Wayne Art School and Museum Fort Wayne, Indiana

Feb. 8-28, 1948 John Herron Art Institute Indianapolis, Indiana

March 8-?, 1948 Brooks Memorial Art Gallery Memphis, Tennessee

April 1- May 2, Addison Gallery 1948

Andover, Massachusetts 
fabric designs, or garment design is unknown.137 It was probably a combination of factors. One advantage may have been the growing fashionability of subdued colors and smaller designs.13日 The royalty figures were based on yardage sold and do not distinguish between textile patterns or completed garment designs. The available figures do not include Palmer's "Horses." Yet, some conclusions can be drawn from the available information on yardage. 139

In total this series sold over 51,000 yards of fabric. The adaptation of Julien Binford's painting "White Chickens" sold the most fabric, close to 8,000 yards. The next highest amounts were for Waldo Pierce's "Cider Press," "Europa and the Nude," and "Trout Fishing," and William Palmer's "Horses" (for the textile print "Horses and Coralls") at an average of 4,000 yards. Sales from textiles adapted Kingman's "Trees," and "White House" as well as Binford's "Fine Creek Mills" ranged from about 2,500 to 3,000 yards. Most of the prints fell in the range of 1,000 to 2,000 yards sold. The least successful prints, Pierce's "Kittens at Play" and "Jardin Aux Lilas," Davis' "Giselle," and Rosenthal 's "Tropical Foliage" (probably "Flowers and Fruit/Papayas)" sold under 900 yards.

Generally, a minimum of three to four yards for each of the outfits in this series; the evening dresses used more fabric than the blouses, and smaller amounts of fabric were used for gloves and scarves. 140 Enough fabric for about 12,500 dresses was sold, with an estimate of about 300 yards reserved for gloves or scarves.141 This number includes possible completed 
garments by designers as well as garments made at home from yardage. This would have been a fairly large number of garments sold in this series.

These dresses probably sold in department stores for somewhere between $\$ 125-\$ 200$ to $\$ 500.142$ These prices ran well below the range of couture fashion which could be several thousand dollars but above everyday ready-to-wear garments which was $\$ 100$ or less.143 The above cost would prevent the average person from being able to afford one of these dresses, except for a special occasion. Most likely these designs were purchased by upper middle class or upperclass women.

Based on the amount of fabric that was sold, the "American Artist Print Series" was a successful venture. The exhibition tour through museums and galleries in major cities very likely contributed to the sales throughout the year of 1947 and into 1948. It would have assured a continued interest in the line of fabrics beyond its opening season.

All evidence points to the overall success of this series. Both the onondaga silk Company and the Midtown Galleries believed this was true and set in motion plans to produce another series of this type. Unfortunately it is unclear how much influence the garment designers and garment designs might have had on the final sales figures for each textile print and on the success of the series as a whole. It also is unknown how much fabric of each print was made of silk or of rayon and whether this had any effect on cost or sales. 
Continuing the Idea

This venture by the onondaga Silk Company and the Midtown Galleries must have been considered successful because onondaga continued to employ a few of the artists it had contracted with in 1946 as well as adding a few more from the the Midtown Gallery over the next few years. In 1948, the Onondaga silk Company and the Midtown Galleries planned a new exhibit titled "Contemporary American Silk Print Series." Included in this series of textile prints were "Children at Play" by Davis, "Mexican water Carriers" by Rosenthal, "Typhoon" by Palmer, "Kentucky" by Peirce, and "Chinese coolies" by Kingman.144

These titles are consistent with the themes that interested these artists. In particular, Rosenthal's "Mexican Water Carriers" is reminiscent of her earlier painting of "Guatemalan Water Carriers," and the textile for Davis" "Children at Play" contains similar figures to those used in "Carousel."145 The Midtown Galleries also sent paintings to onondaga by other artists over the next few years including Lenard Kester, william Thon, Henry Billings, Cecile Belle and Fred Meyer.146

Besides these two collaborations with the Midtown Galleries, little else is known about the Onondaga silk company. These art series seem to have been the only major ventures by Onondaga besides one other similar exhibition with the kennedy Art Galleries of New York City for the Fall of 1947 which focussed on bird imagery in art.147 After these exhibitions, the Onondaga silk Company drifted back into the relative obscurity 
from which it arose to capture the brief interest of the fashion world.

The "American Artist Print Series" in context

The "American Artist Print Series" produced by the onondaga Silk Company in 1947 was an example of the cooperation between the textile industry and the art world that had evolved by the end of world War II. As this study has shown, the industrial and artistic worlds of the first half of the twentieth century fought to keep up with the continuing rapid advances in technology and fashion while social and political changes were taking place around them. Industry worked to anticipate technological and aesthetic changes, looking outside its own sphere for new ideas. Artists sought work in industry, one of the few fields open to them without retraining, during the hard economic times that followed the world wars.

In this atmosphere, the field of textile design flourished. Internationally-known artists designed furnishing materials and apparel items. Their ideas and sketches were translated into surface design for textiles. Many designs also were created by unnamed artists and industrial designers.

The use of actual paintings as inspiration for textile designs evolved by the close of the world war II. For instance, in 1945. Ascher, Ltd. of England produced a series of head scarves called "Modern Art for Daily wear" which were designed by English artists. ${ }^{148}$ zika Ascher believed in bringing art out of museums to the common person and into an everyday context. 
Ascher thought it better that his artists did not understand the field of textiles so as not to be constricted by the pre-set boundaries of the textile medium or the prejudices of the textile designer. ${ }^{149}$

The resulting designs displayed a style of their own, deriving directly from the artists' images. In the case of the Onondaga series, the industrial designers were intermediaries through which the paintings reached their final form. By 1947 , Ascher was adapting the works of many internationally-known painters and sculptors such as Matisse and Henri Moore to textiles.

At this same time the Onondaga Silk Company collaborated with the Midtown Galleries of New York City and its artists to produce an "American Artist Print Series." The principle behind the Onondaga "American Artist Print Series" was similar to Ascher's concept:

Instead of forcing the artist into a scheme wherein he becomes overly aware of the industrialist's promotion plans, the plans are laid later in terms of what the artist has created. 150

For,

...the value of the easel painter to his industrial sponsor is in direct ratio to the complete realization of the painter's aesthetic purposes...151

The six painters chosen for the Onondaga venture represented American artists whose works were traditional rather 
than avant garde. Their genre was primarily American scene and regionalist painting, and their subjects ranged from general landscapes to specific scenes and objects. Their styles varied from impressionistic to graphic, while their mediums included watercolors, pastels, and oils. The final twenty-one images used for this collection dated from the late 1930s to 1946 . Twenty-three textile designs were derived from the paintings and sketches submitted to Onondaga by the Midtown Galleries. These designs varied in style somewhat from the original artists' images, partially through the influence of the industrial designers, and can be compared with the works of abstract expressionists, such as Arshile Gorky and Joan Miro, who were gaining popularity.

Some motifs were modified by the industrial designers as they were translated from the paintings, such as Dong Kingman's "Back Yards," making them suitable for contemporary taste, such as Pierce's "Europa and the Bull." Yet, effort was also made to keep these modifications in the character of the original works. The designs also carried the graphic qualities of the screen printing method used in production. Screen printing had evolved into a popular printing method for the textile industry through experimentation since the early part of the century and from necessity when metal rollers were confiscated for military use during the war years. Trademarks of textile screen printing were larger motifs and design repeats, washes of color, and fine caligraphic lines. 
Once the Midtown paintings were translated into textile designs, they were printed onto rayon and silk crepe. Then the fabrics were given to well-known American clothing designers to be made into fashionable women's day and evening wear which included dresses, suits, blouses and scarves.

Some of these designers, such as Jo Copeland and sophie of Saks adapted the originally flat images of "New Orleans" and "Horses" into shaped garments with little difficulty, using the the print motifs to balance the lines of the dresses. On the other hand, not all designs were successful. Sometimes the print design overpowered the dress design, as in Miss Brownie's interpretation of Doris Rosenthal's "Corn Foliage; "other times the garment design overpowered the print, as in Nettie Rosenstein's adaption of "Cider Press" into evening dresses. Challenges also were presented to the designers by the large sizes of some motifs and pattern repeats.

Yet, as a whole, the garments were consistent with contemporary fashions. Several were reminiscent of conservative styles of earlier decades, such as Mme. Eta's "Clouds and Trees" evening dress, while others showed the experimentation with new ideas of softer lines and draped effects, such as Bruno's dress from Binford's "Woman with a Hat."

The experiments with new styles continued with the attention given to Christian Dior in the year to come. The dress designs were not unfamiliar considering that several designers had utilized them as early as the thirties; draping enjoyed continued popularity through the latter forties. Harper's 
Bazaar announced in its January 1947 issue, before Dior announced his designs, that fine fabrics were returning which were suitable for "the season's gently curved silhouettes."152 These Onondaga fabrics lent thernselves easily to this new silhouette.

Although Christian Dior came out with his "New Look" in Paris one month after the onondaga dresses arrived at the retailers, his "innovative" new style did not have an impact on the American public until later in the spring.153 The "New Look" probably did not overly affect the sales or success of the garments made from onondaga prints because similar styles were already emerging in the fashion world through other designers. The textiles, paintings, and garments were exhibited in museums and galleries in major cities throughout the United States and sold in fashionable department stores. The onondaga venture was successful enough for the company to continue with the concept.

The "American Artist Print Series" very likely appealed to the public because of the innovative use of art in design. This contribution to textile and apparel design certainly interested the educational sphere. Design schools and museums thought it innovative enough to request a showing at their institutions.154

Fortunately, samples and representations of the pieces from from the onondaga series survived for current research. This study provided an opportunity for the pieces to be brought together again and appreciated for their value to industrial design, art history, textile design, and apparel design. In the 
future, further examples of the garments and original paintings may be discovered, as well as the color film that was produced. This study explored an aspect of design history in an effort to understand the relationship of a specific group of textiles to twentieth century textile history. Little work has been done on the relationship between artists, textile design, and industry during the years immediately after world war II. An attempt was made to bring attention to the evolving role of the designer in industry in the early twentieth century.

Most of the artists involved in this collaboration have not been recognized for their work in this field. This study brought contributions of these artists to the attention of researchers and encourages further study of other artists who may have also been involved in similar endeavors. Many other artists like these have yet to be discovered.

The role of the apparel designer was examined through the production of the garments. In this particular series, the designers' efforts to adapt two-dimensional images into threedimensional forms was extremely important to the success of the finished garments. Cut, construction, and shaping had to consider fabric and print design while still following contemporary styles. Although current scholarship recognizes the work of some of these designers, this research indicated that most were well known in the forties.

The idea of combining art with textile design continued to appeal to the international design scene after 1947. In 1953, the Institute of Contemporary Arts in Britain produced a series, 
"Paintings into Textiles," following this trend.155 Series of this type were overshadowed as the world of textile design and industry moved towards geometric, abstract and biomorphic images in the $1950 \mathrm{~s}$. Today, the textile industry still produces printed scarves using images of well-known artists. 


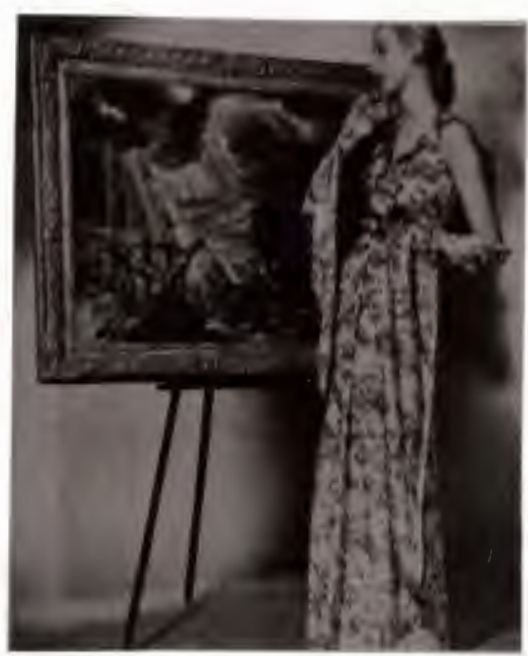

A

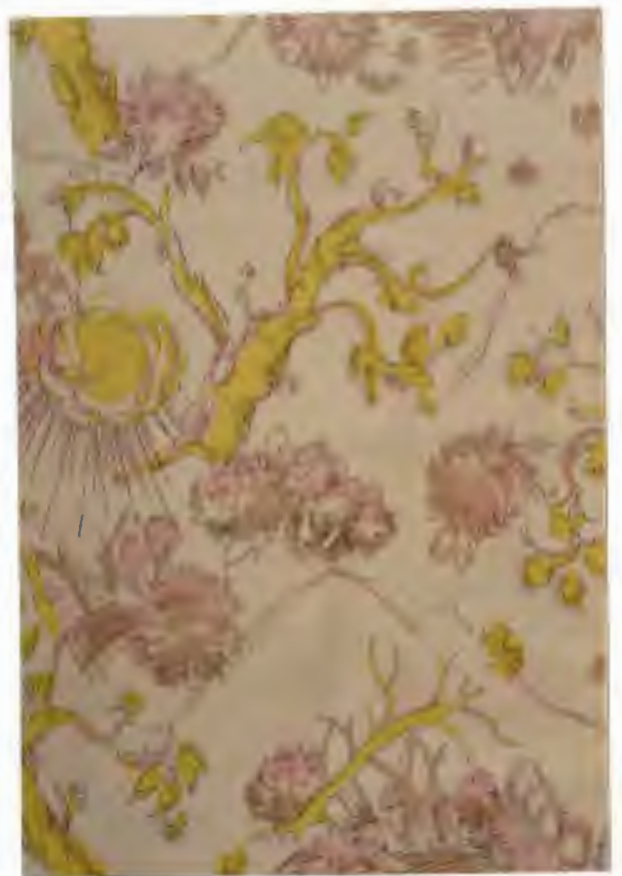

B

FIGURE 1

A. "Sun, Water, And Air" Painting by William Palmer, Dress by Emmet Joyce of Samuel Kass, Inc. (Artnews)

B. "Sun, Water, And Air" Textile Design by the Onondaga Silk Company. (RISD 47.121) 


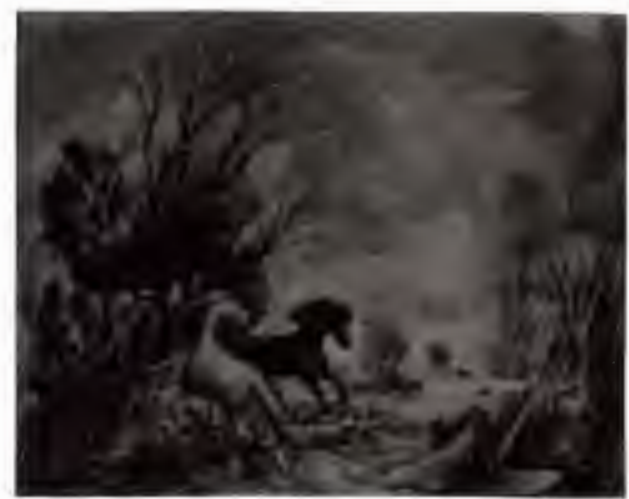

A

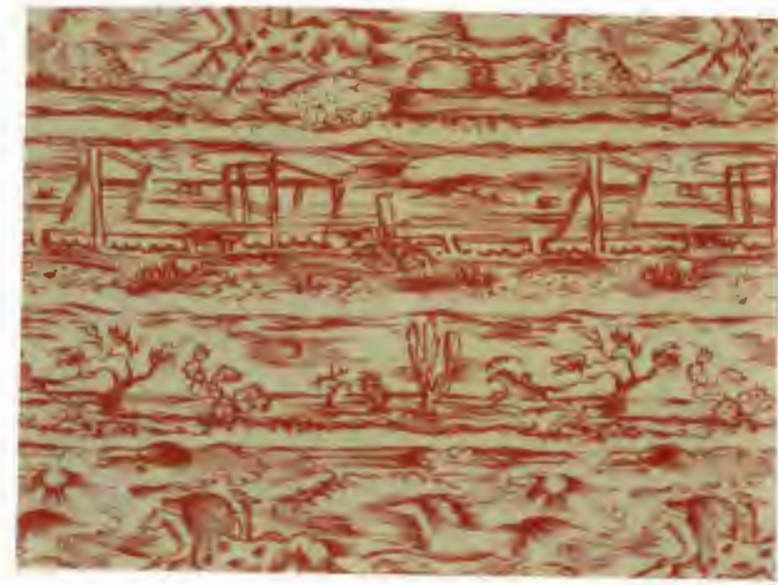

B

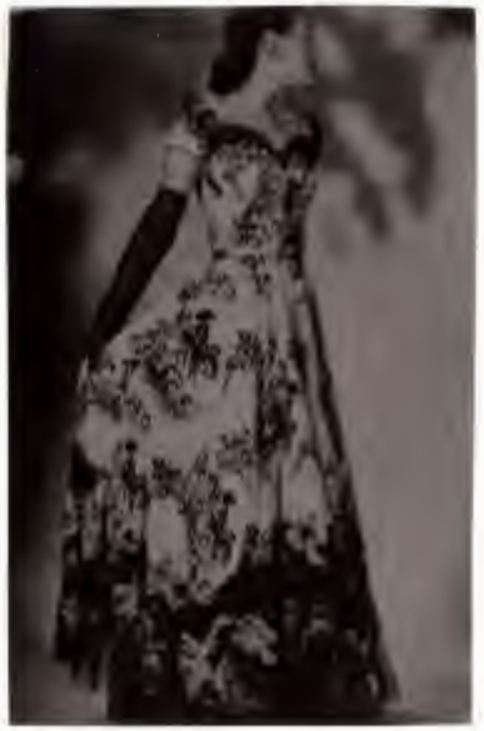

$\mathrm{C}$

\section{FIGURE 2}

A."Horses" Painting by William Palmer. (Artnews)

B. "Horses and Corrals" Textile Design by the Onondaga Silk Company. (RISD 47.114)

C."Horses" Dress by Sophie of Saks. (Artnews) 


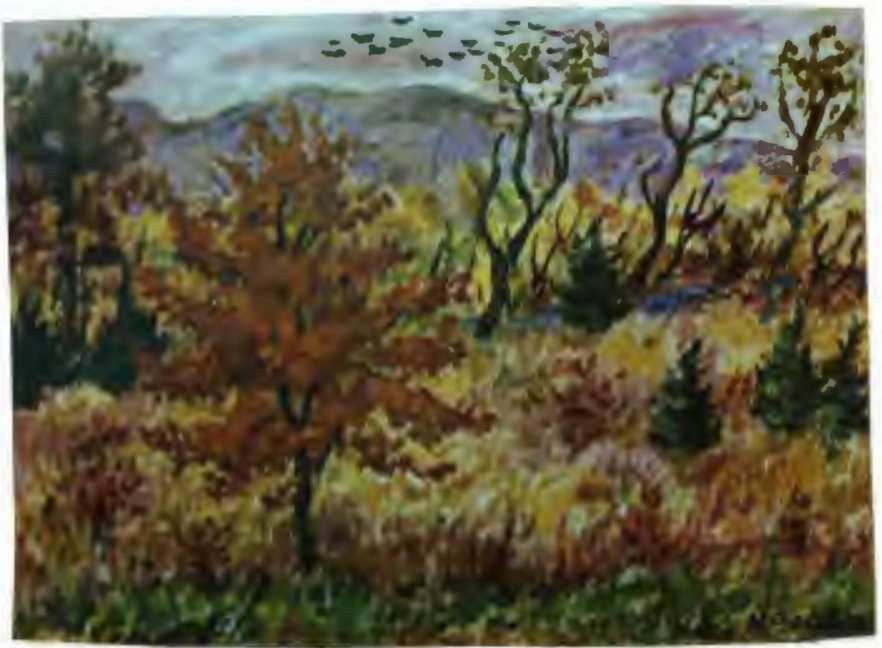

A

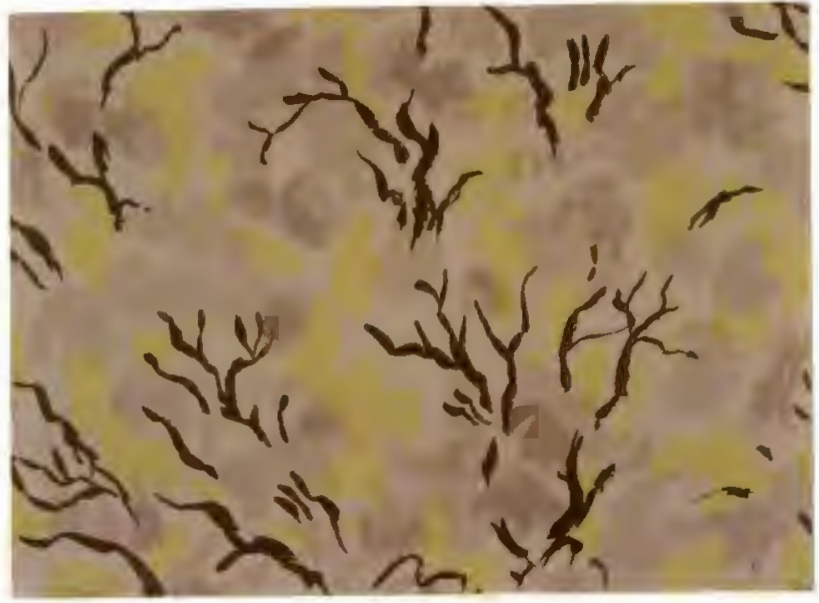

B

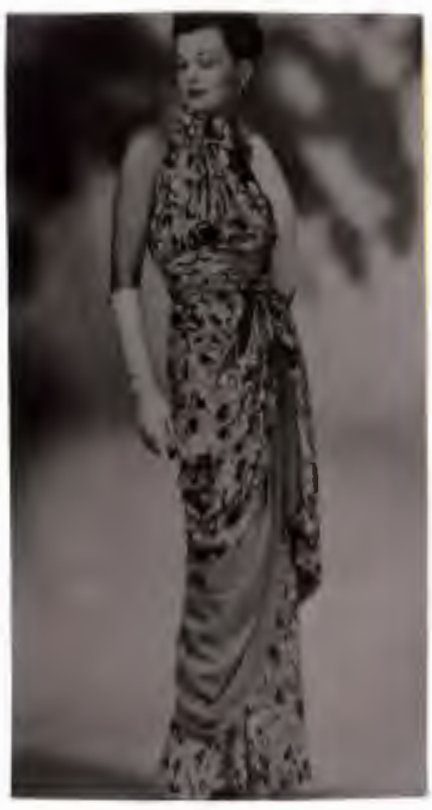

$\mathrm{C}$

FIGURE 3

A."The Dogwood's Last Stand"Painting by Waldo Peirce. B."Clouds and Trees" Textile Design by the Onondaga Silk Company. (RISD 47.125 )

C. "Clouds and Trees" Dress by Eta of Ren-Eta. (Artnews) 


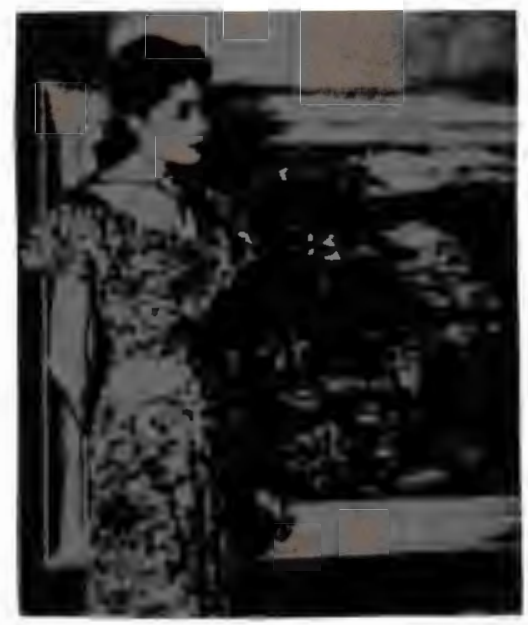

A

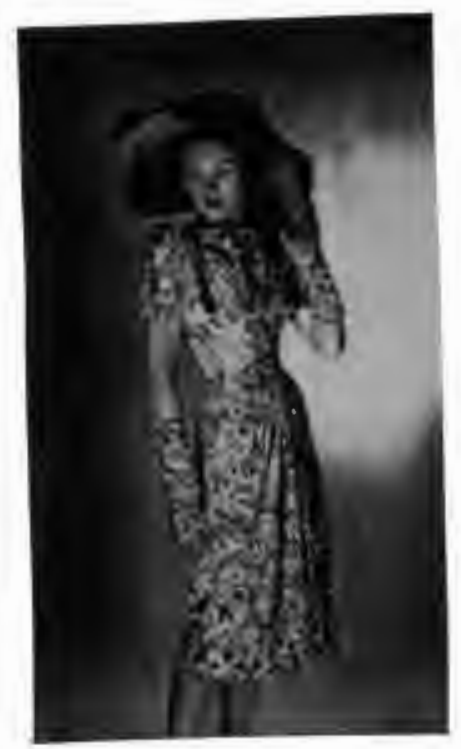

B

FIGURE 4

A. "Cider Press" Painting by waldo Peirce, Evening Dress by Nettie Rosenstein. (The New York Times)

B. "Cider Press" Afternoon Dress by Nettie Rosenstein. (Bloomingdale collection, Catalogue) 


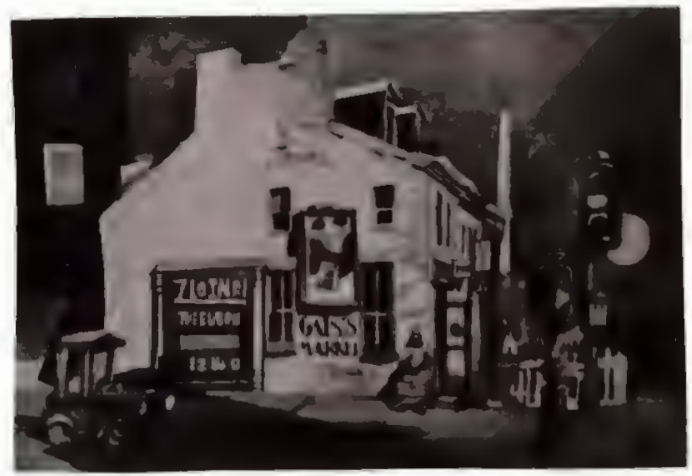

A

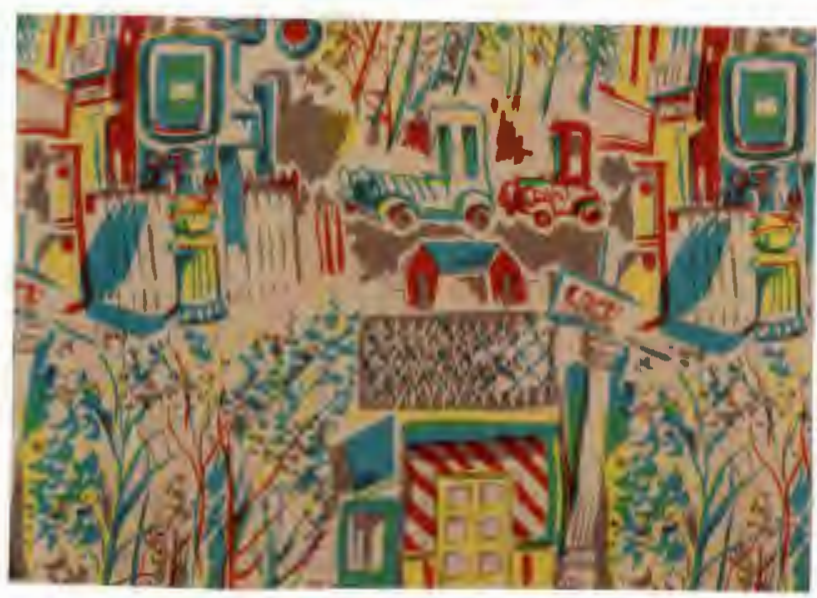

B

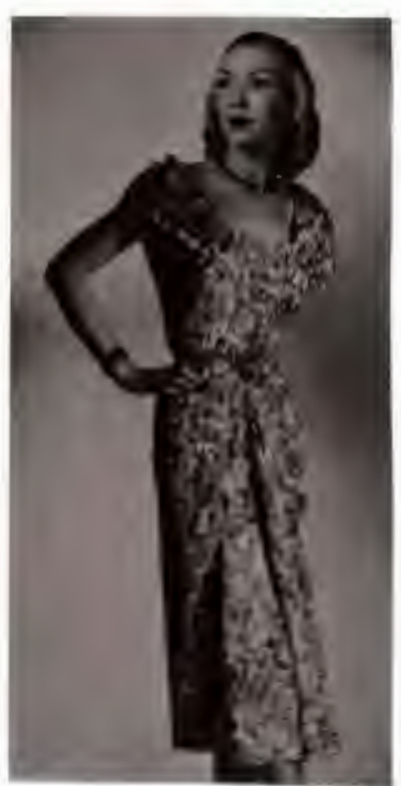

C

\section{FIGURE 5}

A. "White House" Painting by Dong Kingman. (American Artist)

B. "New Orleans" Textile Design by the Onondaga Silk Company. (RISD 47.129)

C. "New Orleans" Dress by Jo Copeland of Patullo. (American Artist) 


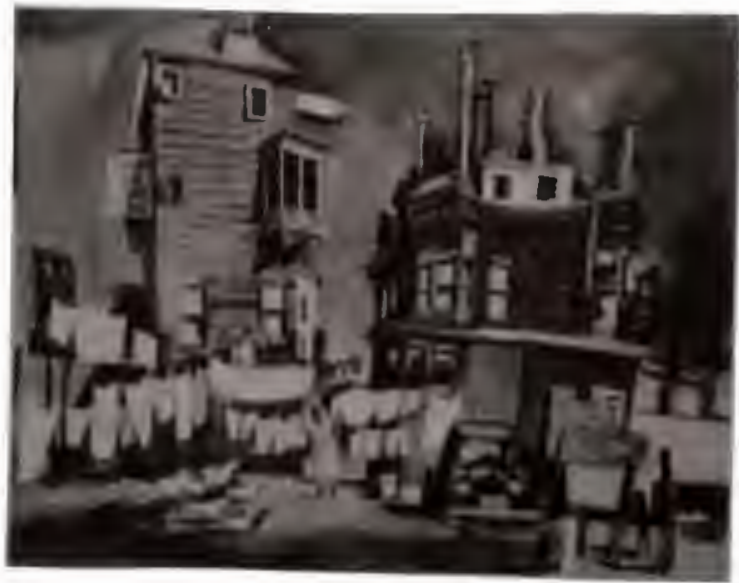

A

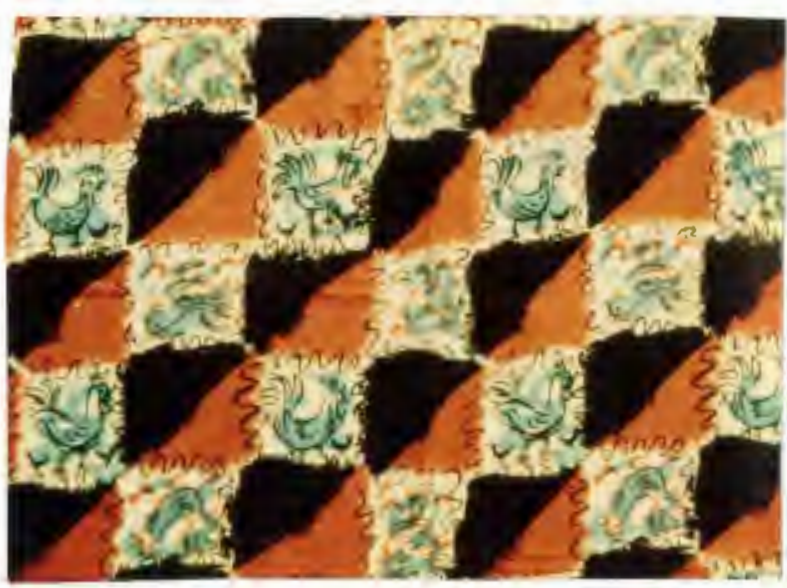

B

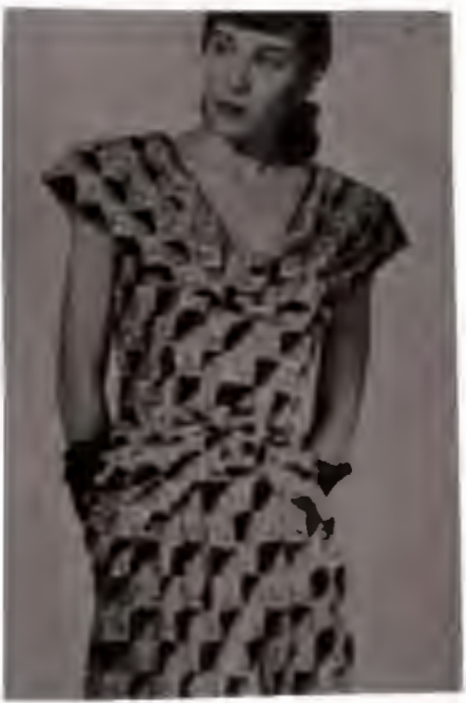

C

FIGURE 6

A."Back Yards" Painting by Dong Kingman.

B. "Chickens in Squares" Textile Design by the Onondaga Silk Company. (Artnews)

C. "Chickens in Squares" Dress by Jo Copeland of Patullo. (Artnews) 


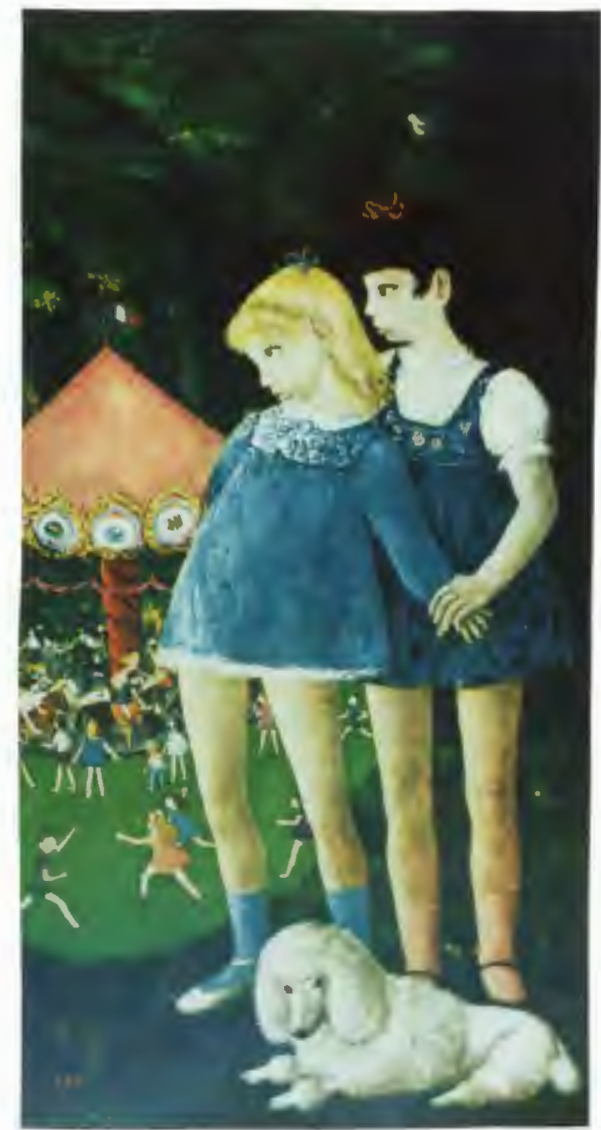

A

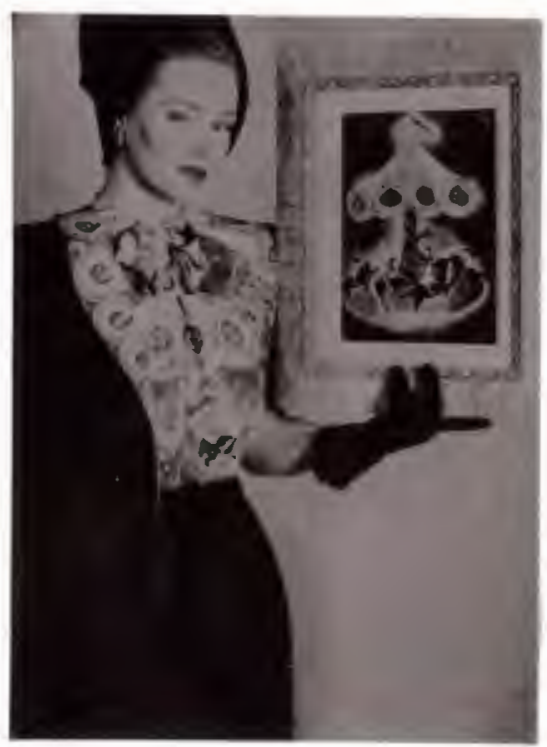

B

\section{FIGURE 7}

A. "Carousel" Painting by Gladys Rockmore Davis. (Artnews) B. "Carousel" Textile Design by the Onondaga Silk Company, Dress by Nettie Rosenstein. (Artnews) 


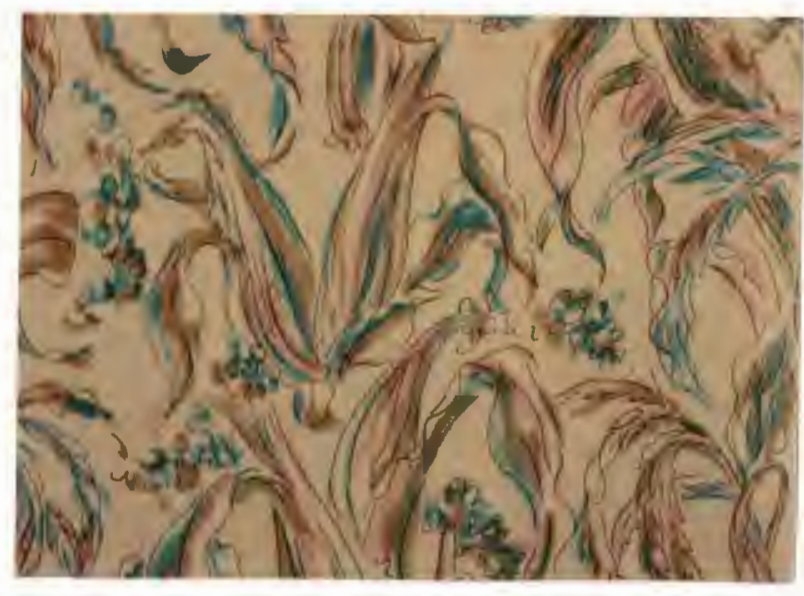

A

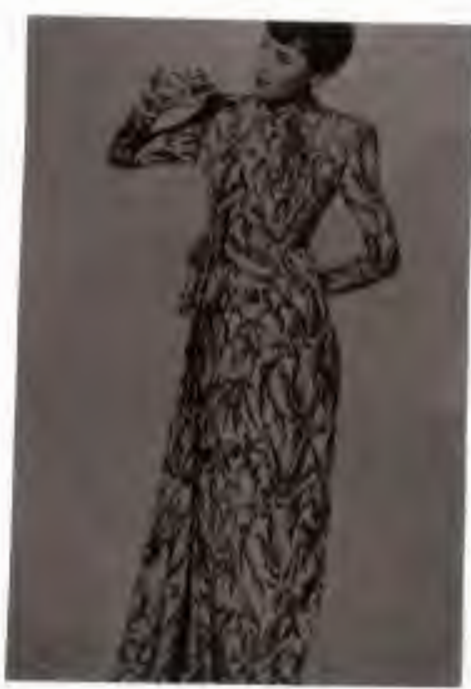

B

FIGURE 8

A. "Corn Foliage" Textile Design by the Onondaga Silk Company. (RISD 47.122 )

B. "Corn Foliage" Evening Dress by Brownie of Foxbrownie. (Artnews) 


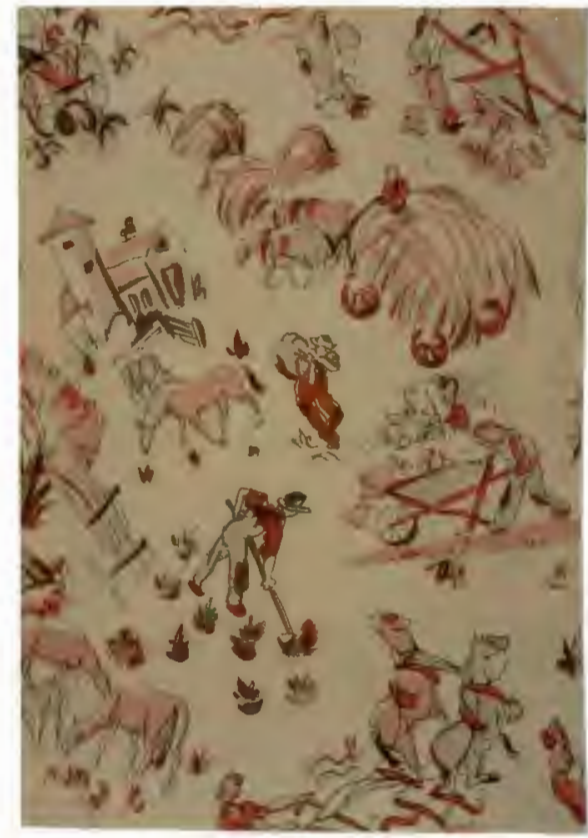

A

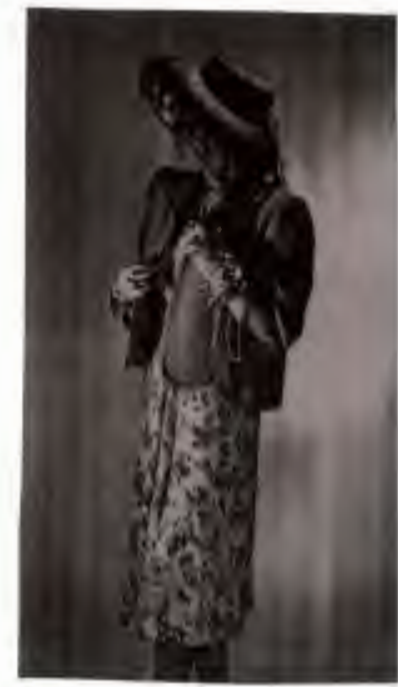

B

FIGURE 9

A. "Fine Creek Mills" Textile Design by the Onondaga Silk Company. (RISD 47.127)

B. "Fine Creek Mills" Afternoon Dress by Brownie of Foxbrownie. (Bloomingdale collection) 


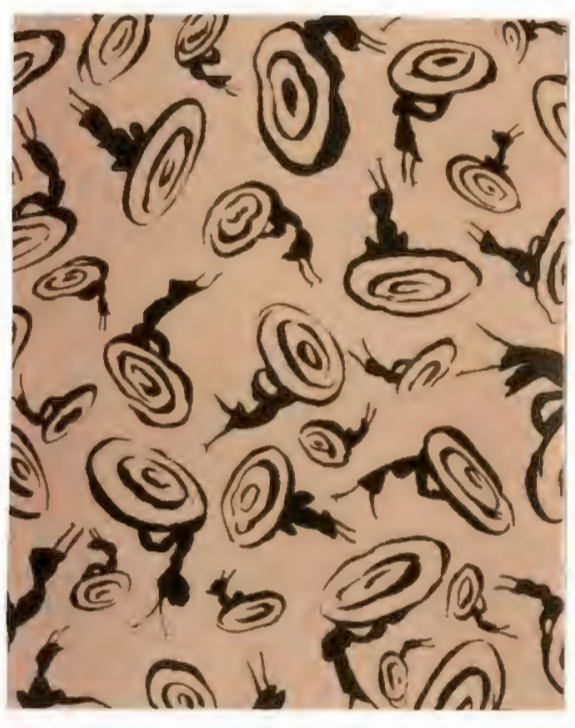

A

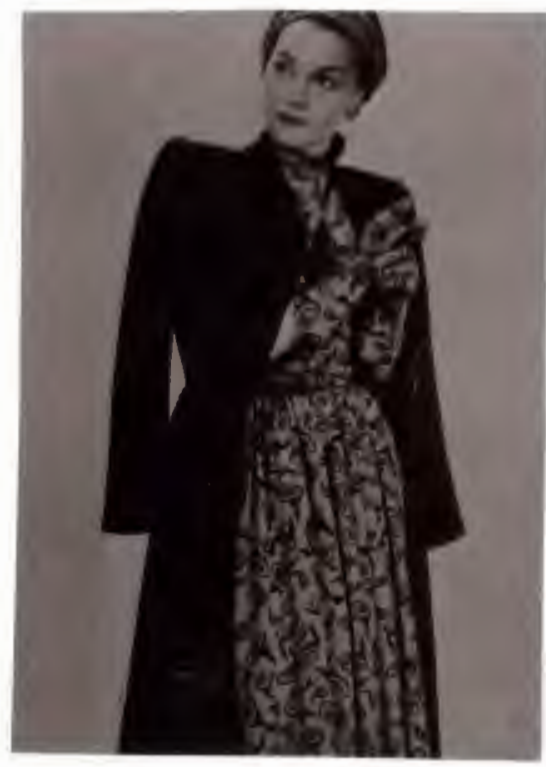

B

\section{FIGURE 10}

A. "Woman with a Hat" Textile Design by the Onondaga Silk Company. (RISD 47.128)

B. "Woman with a Hat" Dress by Bruno of spectator Sports. (Artnews) 


\section{LITERATURE CITED}

1 Some of these issues were mentioned briefly by Jan Reeder in a presentation entitled "Society on Silk: Prints from the 1920s and 30s," at the Fashion Institute of Technology, New York City, April 261993.

2 Lola Mcknight is one researcher currently studying the stehli Silk Company and the fabric prints produced by it.

3 Whitney Blausen has recently been studying the life and work of Ruth Reeves. See Whitney Blausen, "Ruth Reeves'

'Personal Prints:' Printed Textiles from the 1930s and 1940s," proceedings of the Third Biennial Symposium of the Textile

Society of America (Seattle, Washington: n.p., September 24-26, 1992), pp. 163-167.

4 Marianne Carlano and Nicola J. Shilliam, Early Modern Textiles: From Arts and Crafts to Art Deco, Exhibition and Catalogue, (Boston: Museum of Fine Arts, 1993).

5 For an extensive discussion of the development and influence of the Arts and Crafts Movement, see Linda Parry, Textiles of the Arts and crafts Movement, (London: Thames and Hudson, 1988).

6 Mary Schoeser, Twentieth Century Design Fabrics and

Wallpapers, (London: Bell and Hyman, 1986), p. 14; Penny Sparke, An Introduction to Design and culture in the Twentieth Century,

(Boston: Allen and Unwin, 1986), pp. 95.

7 For further background on the beginnings of twentiethcentury design see: Jonathan M. Woodham, Twentieth-Century ornament, (New York: Rizzoli, 1990), foreword; Sparke, pp. xxi, 15; see also Dorothy Grafly, "Industrial Design, " Design 48 (5) January 1947: 16; and Felix Payant, "Design in America." Design vol. 48, no. 3 (November, 1946), p. 3 .

8 Lisa Phillips and Bletter, Rosemarie Haag, eds., High Styles: Twentieth-Century American Design, (New York: Summit Books, 1985), p. 113.

9 Mary Schoeser and Celia Rufy, English and American Textiles from 1790 to the Present, (New York: Thames and Hudson, 1989), p. 182; Schoeser, p. 185.

10 "Textile Design and the Artist," Design 48(6): 22.

11 schoeser and Rufy, p. 28.

12 Alstair Duncan, The Encyclopedia of Art Deco, (New York: E.P. Dutton, 1988), p. 179; Stuart Robinson, A History of Printed Textiles, (Cambridge, Ma.: The MIT Press, 1969), pp. 158-159.

13 "Art into Living Silk Prints 1947," Art News, vol. 45, no. 11, p. 63 .

14 Duncan, p. 173 . 
15 Schoeser, p. 83; Woodham, p. 61, 199; Robinson, p. 49; Design: 1935-1965; What Modern Was p. 242; See also Valerie D. Mendes and Frances M. Hinchcliffe, Ascher: Fabric. Art and Fashion, (Cambridgeshire: Balding and Mansell, 1987).

16 Sparke, pp. 91, 82 .

17 Oliver w. Larkin, Art and Life in America, (New York: Holt, Rinehart and Winston, 1960), p. 409.

18 Sparke, p. 177.

19 Schoeser and Rufy, p. 184.

20 Schoeser, p. 28.

21 Woodham, pp. 158-159.

22 Edmund Knecht and James Best Fothergill, The Principles and Practice of Textile Printing, (London: Charles Griffin and Company, Ltd, 1952), p. 69.

23 Lloyd Goodrich and John I.H. Baur, American Art of our Century, (Frederick A. Praeger Publishers, 1961), p. 197.

24 Felix Payant, p. 3.

25 Barbara Rose, American Painting: The Twentieth Century, (New York: Rizzoli International Pub., 1986), pp. 13, 60,61; Guy Davenport, "Civilization and Its Opposite in the Nineteenforties," in Art of the Forties (New York: The Museum of Modern Art, 1991) pp.15.

26 "Mill Notes," American Wool and Cotton Reporter, 9 June 1925, p. 75; In 1925 the Onondaga Silk Company was taken over by an engineering firm by the name of Ford, Bacon, and Davis but continued to produce under its own name (see "Tex.Cos. Helped By outside Experts" New York Times 20 July 1930, sec. N, p. 19).

27 New York Times 4-2-1930, Smithsonian Institution Archives of American Art, Washington, D.C., Midtown Galleries Records \$f1932-1983, series II Exhibitions, box on onondaga.

28 Ibid.

29 Davison's Textile Blue Book, (Ridgewood, N.J.: Davison Publishing Company, Inc., 1945-55), under Easton, Pennsylvania. 30 "From a Kingman Watercolor into a Silk Print for Onondaga, " American Artist (March 1947), p. 46.

31 Virginia Pope, "Figured Silks and Rayons Exhibited with Art Works that Provided Motifs, " New York Times December 17, 1947, p. 41.

32 Letter to Miss Elizabeth McCausland of the Springfield Republican, December 6, 1946, Smithsonian Institution Archives of American Art, Washington, D.C., Midtown Galleries Records $\$$ f1932-1983, series II Exhibitions, box on Onondaga.

33 Rose, pp.17, 19, 46, 50.

34 American Artists: An Illustrated Survey of Leading Contemporary Americans (New York: Facts on File Publications, 1985), p. 253 .

35 National Cyclopedia of American Biography vol. 55, (New York: James T. White, 1974), p. 376. 
36 "The Watercolor Series: Dong Kingman, "American Artist (September 1947), pp. 42-3, 45.; Who's who in American Art 198990 18th edition (New York: R.R. Bowker, 1989), p. 570; Who's Who in American Art 1993-94, 20th edition (New York: R.R. Bowker, 1993), p. 629 .

37 Who was who in America vol. 4 (Chicago: Marquis who's Who, Inc., 1968), p. 233; Jim Collins and Glen B. Opitz, eds., Women Artists in America $18 \mathrm{th}$ century to the Present $(1790-1980)$ (Poughkeepsie, New York: Apollo, 1980).

38 Collins and Opitz, whe was who in America vol. 5

(Chicago: Marquis who's Who, Inc., 1973), p. 621.

39 Peter Hastings, ed., Who Was who in American Art

(Connecticut: Sandview Press, 1985), p. 55.

40 Invitation form letter from A.D. Gruskin of the Midtown Galleries, Smithsinian Institution Archives of American Art, Washington, D.C., Midtown Galleries Records \$fl932-1983, series II Exhibitions, box on Onondaga.

41 This list is of titles as they were referred to by Midtown Galleries, Archives of American Art, Washington, D.C., Midtown Galleries Records \$f1932-1983, series II Exhibitions, box on Onondaga.

42 Ibid.

43 Rose, p. 19.

44 See Diana Emery Hulick, Waldo Peirce: A New Assessment 1884-1970, with and Essay by Robert F. Brown (Orono: University of Maine, 1984).

45 Compiled from textiles, archive references, and artist listings, as well as article references. In some cases it was found that a painting or a textile was referred to with more than one name. In this table these names have been combined where there is evidence to support the fact that although the titles are different the actual pieces being referred to are the same.

46 The reference to the painting "Back Yard" is likely referring to a work titled "Back Yards." The latter title with the "s" fits the description of the interpretation of the painting into the textile design given by the industrial

designers. It is also the only version with a similar title, subject matter and date found (See Figure 6A). Correspondence between Alan Gruskin and Charles Moselle (26 February 1947) concerning a list of the Paintings sent to Riche's of Atlanta lists this painting as "Back Yards," Smithsonian Institution Archives of American Art, Washington, D.C., Midtown Galleries Records $\$ f 1932-1983$, series II Exhibitions, box on onondaga. Another list from the archives of the st. Louis Art Museum also refers the painting in the same way. See The Saint Louis Art Museum, saint Louis, Missouri, Exhibition Files: Silk in Search of Six Painters, 1947.

47 The textile design "Papayas" is listed in an exhibition label as having "evolved from two of her paintings," mentioning 
"Fruit on Table" while another textile design "Papayas" is listed as originating from a painting titled "Flowers and Fruit." Unfortunately no evidence was found to clarify the confusion set by these paintings and designs. Another painting also has been mentioned called "Tropical Foliage," but what relationship it has to these others or to the series produced by Onondaga is unclear. Smithsonian Institution Archives of American Art, Washington, D.C., Midtown Galleries Records \$f1932-1983, series II Exhibitions, box on Onondaga.

48 woodham, p. 166; An image of Pierce's "Europa and the Bull" is located in the files on the exhibition in the archives of the Addison Gallery of American Art, Phillips Academy, Andover, Massachusetts.

49 Rose, pp. $54,58$.

50 An image of Kingman's "Trees" is located in the files on the exhibition in the archives of the Addison Gallery of American Art, Phillips Academy, Andover, Massachusetts.

51 Dong Kingman, "The Making of a Watercolor" in The Watercolors of Dong Kingman, and How the Artist Works (New York: The Studio Publications, Inc., 1958), p.123; Alan D. Gruskin, "The Story of the Artist" in The Watercolors of Dong Kingman. and How the Artist Works (New York: The Studio Publications, Inc., 1958), pp. 21-61.

52 Who was who in America vol. 4 (Chicago: Marquis Who's Who, Inc., 1968), p. 233; Jim Collins and Glen B. Opitz, eds., Women Artists in America 18th Century to the Present (1790-1980)

53 Exhibition Label Description, Archives of American Art, washington, D.C., Midtown Galleries Records \$f1932-1983, series II Exhibitions, box on Onondaga.

54 A photo of the dress with painting of "Ballet slippers" is in the Smithsonian Institution Archives of American Art, Washington, D.C., Midtown Galleries Records \$f1932-1983, series VI, box 6: Photographs. "Carousel" is depicted on the cover of Artnews, vol. 45, no. 11 .

55 See Appendix B of this work for other titles.

56 Collins and Opitz, whe was who in America, p. 621.

57 Exhibition Label Description, Smithsonian Institution Archives of American Art, Washington, D.C., Midtown Galleries Records \$f1932-1983, series II Exhibitions, box on Onondaga.

58 Archives of American Art; see Appendix B for an extended list of titles submitted to Onondaga by Binford.

59 Rose, pp. 7-19.

60 See further Michael ward, Art and Design in Textiles,

(New York: Van Nostrand Reinhold Co., 1973), pp. 19-20.

61 "From a kingman watercolor into a Silk Print for

Onondaga," American Artist (March 1947), p. 46.

62 Examples of this pattern come from the Textile

Collection of the Museum of Art, Rhode Island School of Design, 
Providence, Rhode Island, (47.121RISD), and the Smithsonian Institution Archives of American Art, Washington, D.C., Midtown Galleries Records $\$ f 1932-1983$, series V, box 2; fabric samples. 63 Exhibition label description, Smithsonian Institution Archives of American Art, washington, D.C., Midtown Galleries Records $\$ f 1932-1983$, series II Exhibitions, box on Onondaga.

64 An example of the blue silk is at the Smithsonian Institution Archives of American Art, Washington, D.C., Midtown Galleries Records \$f1932-1983, series $V$, box 2 : fabric samples, while a piece of the red rayon is in the Textile collection, the Museum of Art, Rhode Island School of Design, Providence, Rhode Island, (47.114RISD).

65 The colors were described in the label copy in the Archive notes.

66 Exhibition label description, Smithsonian Institution Archives of American Art, washington, D.C., Midtown Galleries Records $\$ f 1932-1983$, series II Exhibitions, box on onondaga. An image of Pierce's "Europa and the Bull" is located in the files on the exhibition in the archives of the Addison Gallery of American Art, Phillips Acadeny, Andover, Massachusetts. The example of this textile pattern is at the Smithsonian Institution Archives of American Art, Washington, D.C., Midtown Galleries Records \$f1932-1983, series V, box 2: fabric samples.

67 Exhibition label description, Smithsonian Institution Archives of American Art, Washington, D.C., Midtown Galleries Records \$f1932-1983, series II Exhibitions, box on onondaga.

68 Examples of this pattern in brown are in the smithsonian Institution Archives of American Art, Washington, D.C. , Midtown Galleries Records $\$ 1932-1983$, series $V$, box 2: fabric samples; and in the Textile collection, the Museum of Art, Rhode Island School of Design, Providence, Rhode Island, (47.123RISD). The exhibition label description at the smithsonian Institution Archives of American Art, Washington, D.C. , Midtown Galleries Records \$f1932-1983, series II Exhibitions, box on onondaga, notes the other colorways of the print.

69 An example of this fabric exits in the form of a completed dress at the costume Institute, the Metropolitan Museum of Art, New York City, (CI47.74.16abcd).

70 Exhibition label description, Smithsonian Institution Archives of American Art, Washington, D.C., Midtown Galleries Records \$f1932-1983, series II Exhibitions, box on onondaga.

71 The former is in the caption of Rosamund Frost's article, "Silk in Search of Six Painters," Artnews vol. 45, no, 11 , p. 31, and is mentioned in the exhibition label description, Smithsonian Institution Archives of American Art, Washington, D.C. . Midtown Galleries Records $\$ f 1932-1983$, series II Exhibitions, box on Onondaga, while the latter is included in the Textile collection of the Museum of Art, Rhode Island school of Design, Providence, Rhode Island, (47.125RISD). 
72 Exhibition label description, Smithsonian Institution Archives of American Art, Washington, D.C., Midtown Galleries Records $\$ f 1932-1983$, series II Exhibitions, box on onondaga.

73 Exhibition label description, Smithsonian Institution Archives of American Art, Washington, D.C., Midtown Galleries Records \$f1932-1983, series II Exhibitions, box on Onondaga; Smithsonian Institution Archives of American Art, Washington, D.C., Midtown Galleries Records $\$ f 1932-1983$, series V, box 2 : fabric samples. An example of this print is also in the collection of the Cleveland Museum of Art, Cleveland, Ohio, $(47.108)$.

74 Exhibition label description, Smithsonian Institution Archives of American Art, Washington, D.C., Midtown Galleries Records \$f1932-1983, series II Exhibitions, box on onondaga.

75 Samples of this textile print are in the collections of Smithsonian Institution Archives of American Art, Washington, D.C., Midtown Galleries Records \$f1932-1983, series V, box 2: fabric samples, and the Textile collection of the Museum of Art, Rhode Island School of Design, Providence, Rhode Island, (47.129RISD).

76 Exhibition label description, Smithsonian Institution Archives of American Art, Washington, D.C., Midtown Galleries Records \$£1932-1983, series II Exhibitions, box on Onondaga.

77 This description comes from a caption in Rosamund Frost's article as well as the catalog card from the Textile Collection of the Museum of Art, Rhode Island School of Design, Providence, Rhode Island, (47.113RISD); a sample of this textile is at the Smithsonian Institution Archives of American Art, Washington, D.C., Midtown Galleries Records \$f1932-1983, series $\mathrm{V}$, box 2: fabric samples.

78 Exhibition label description, Smithsonian Institution Archives of American Art, Washington, D.C., Midtown Galleries Records \$f1932-1983, series II Exhibitions, box on Onondaga.

79 The sample studied is in the Textile collection of the Museum of Art, Rhode Island School of Design, Providence, Rhode Island, (47.124RISD). An image of the full design repeated in four directions is in the archives of the Addison Gallery of Art, Phillips Academy, Andover, Massachusetts.

80 A full width sample of this pattern is at the Smithsonian Institution Archives of American Art, washington, D.C., Midtown Galleries Records \$f1932-1983, series V, box 2 : fabric samples, while a smaller piece is at the Textile Collection of the Museum of Art, Rhode Island School of Design, Providence, Rhode Island, (47.119RISD). The exhibition label description in Smithsonian Institution Archives of American Art. washington, D.C., Midtown Galleries Records $\$$ f1932-1983, series II Exhibitions, box on Onondaga, describes the interpretation from the painting.

81 Samples of this pattern are at the Smithsonian Institution Archives of American Art, Washington, D.C., Midtown Galleries Records \$f1932-1983, series V, box 2: fabric samples, 
and at the Textile collection of the Museum of Art, Rhode Island School of Design, Providence, Rhode Island, (47.126RISD).

82 Exhibition label description in Sinithsonian Institution Archives of American Art, Washington, D.C., Midtown Galleries Records $\$ f 1932-1983$, series II Exhibitions, box on Onondaga.

83 A sample of this print is in the Textile collection of the Museum of Art, Rhode Island School of Design, Providence, Rhode Island, (47.122RISD) .

84 Samples of this print are in the Smithsonian Institution Archives of American Art, Washington, D.C., Midtown Galleries Records \$f1932-1983, series $V$, box 2: fabric samples, and in the Textile collection of the Museum of Art, Rhode Island School of Design, Providence, Rhode Island, (47.116RISD), and the motifs are described in the exhibition label, Smithsonian Institution Archives of American Art, Washington, D.C., Midtown Galleries Records \$f1932-1983, series II Exhibitions, box on Onondaga. An image of the painting, textile design and dress are in the Smithsonian Institution Archives of American Art, Washington, D.C., Midtown Galleries Records \$f1932-1983, series VI, box 6 : Photographs.

85 Exhibition label description, Smithsonian Institution Archives of American Art, Washington, D.C., Midtown Galleries Records \$f1932-1983, series II Exhibitions, box on Onondaga.

86 Examples of the former is in the Smithsonian Institution Archives of American Art, Washington, D.C., Midtown Galleries Records \$f1932-1983, series $V$, box 2 : fabric samples, and in the Textile Collection of the Museum of Art, Rhode Island School of Design, Providence, Rhode Island, $(47,127 \mathrm{RISD})$, while the latter is in a dress at the costume Institute, the Metropolitan Museum. of Art, New York City, (47.74.92ab).

87 Exhibition label description, Smithsonian Institution Archives of American Art, Washington, D.C., Midtown Galleries Records $\$ f 1932-1983$, series II Exhibitions, box on Onondaga.

88 An example of the first color combination can be seen at the Smithsonian Institution Archives of American Art, Washington, D.C., Midtown Galleries Records \$f1932-1983, series $\mathrm{V}$, box 2: fabric samples, and the second in the Textile Collection of the Museum of Art, Rhode Island School of Design, Providence, Rhode Island, (47.128RISD).

89 Grace Margaret Morton. The Arts of Costume and Personal Appearance, 3rd ed., (New York: John Wiley and Sons, Inc., 1966), pp. 67-116.

90 Ibid.

91 Ibid.

92 Georgina Howell, In Vogue: Sixty years of international celebrities and fashion from British Voque, (New York: Schoken Books, 1976), pp. 141, 179 .

93 Caroline Reynolds Milbank, New York Fashion: The Evolution of American Style, (New York: Harry N. Abrams, Inc., 1989), pp. 134-136. 
94 See Howell, p. 146, and Harper's Bazaar (October 1946), p. 224; Harper's Bazaar (November 1946), p. 213; Harper's Bazaar (March 1947), pp. 217, 224.

95 Elizabeth Ewing, History of Twentieth Century Fashion (Totowa, N.J.: Barnes and Noble, 1986), p. 121.

96 Milbank, p. 132.

97 "From a Kingman watercolor into a Silk Print for Onondaga," American Artist (March 1947), p. 46; Some of these designers have worked with other fabrics produced by this company, see "Swing to Pleats," Harper's Bazaar 81 (February 1947), p. 232-233, for a design by Jo Copeland.

98 Caroline Reynolds Milbank, New York Fashion: The Evolution of American Style, (New York: Harry N. Abrams, Inc., 1989), pp. 73, 132, 152 .

99 Milbank, pp. 92; "Swing to Pleats." Harper's Bazaar (Feb 1947): 69 .

100 Milbank, p. 152; Harper's Bazaar (October 1946): 115; Harper's Bazaar (Nov 1946): 78; Harper's Bazaar (Dec 1946): 21; Harper's Bazaar (Feb 1947): 124; Harper's Bazaar (April 1947): 52,111

101 Milbank, pp. 138, 166-67.

102 Milbank, pp. 117, 119.

103 Milbank, p. 127.

104 Ibid.

105 Milbank, p. 132 .

106 Smithsonian Institution Archives of American Art, Washington, D.C., Midtown Galleries Records \$f1932-1983, series II Exhibitions, box on Onondaga.

107 Milbank, p. 184.

108 Harper's Bazaar (October 1946): 66, 67; Milbank, p. 125 .

109 Milbank, p. 114.

110 Milbank, p. 126.

111 Exhibition label description, Smithsonian Institution Archives of American Art, washington, D.C., Midtown Galleries Records \$f1932-1983, series II Exhibitions, box on Onondaga. 109-111.

112 An image of this dress in in Frost, p. 59; Ewing, pp.

113 An image of this dress is in Frost, p. 31, 33.

114 Ibid.

115 Photographs of this dress are in the collection of the Smithsonian Institution Archives of American Art, Washington, D.C., Midtown Galleries Records \$f1932-1983, series VI, box 6: Photographs, and the files of the Saint Louis Art Museum, Saint Louis, Missouri.

116 An image of this dress is in Rosamund Frost's article in Artnews, p. 31.

117 Robinson, pp. 48, 49. 
118 This dress was photographed for Pope's article in the New York Times.

119 Photograph from the Smithsonian Institution Archives of American Art, Washington, D.C., Midtown Galleries Records \$fl932-1983, series VI, box 6: Photographs.

120 An example of this dress in in the costume Institute, the Metropolitan Museum of Art, New York City, (CI47.74.16abcd). 121 An image of this dress is in American Artist (March $1947): 44$.

122 An image of this garment is in Frost's article, p. 32, as well as in the Smithsonian Institution Archives of American Art, Washington, D.C. , Midtown Galleries Records \$f1932-1983, series VI, box 6: Photographs.

123 An image of this garment is in Frost's article, p. 60, as well as in the Smithsonian Institution Archives of American Art, Washington, D.C., Midtown Galleries Records \$f1932-1983, series VI, box 6: Photographs.

124 Photograph in the Smithsonian Institution Archives of American Art, Washington, D.C., Midtown Galleries Records \$f1932-1983, series VI, box 6: Photographs.

125 Photograph in the Smithsonian Institution Archives of American Art, Washington, D.C., Midtown Galleries Records \$1932-1983, series VI, box 6: Photographs.

126 Joset Walker's design appears in Frost, p. 33, while the other design is a photograph in the Smithsonian Institution Archives of American Art, Washington, D.C., Midtown Galleries Records \$f1932-1983, series VI, box 6: Photographs.

127 An example of this dress is at the costume Institute, the Metropolitan Museum of Art, New York City, (47.74.92ab).

128 This design appears in Frost's article, p. 32, with a coat, and in a photograph in the smithsonian Institution Archives of American Art, Washington, D.C., Midtown Galleries Records \$f1932-1983, series VI, box 6: Photographs.

129 See further Harper's Bazaar (October 1946-May 1947) for an overview.

130 Unfortunately, an example of the film has yet to be discovered. It was mentioned in a telegram to one of the artists, as well as in several news releases and write-ups in the records at the Smithsonian Institution Archives of American Art, Washington, D.C., Midtown Galleries Records \$f1932-1983, series II Exhibitions, box on Onondaga. It was included along with the textiles and paintings in the publicity material sent to the Addison Gallery of Art, Phillips Academy, Andover, Massachusetts.

131 Smithsonian Institution Archives of American Art, washington, D.C., Midtown Galleries Records \$f1932-1983, series II Exhibitions, box on Onondaga.

132 see Table 2 of this work.

133 Ibid. 
134 This catalogue is in the costume Institute, the Metropolitan Museum of Art, New York City.

135 Ibid.

136 Compiled from two separate lists, one general and the other more specific, both from the Smithsonian Institution Archives of American Art, Washington, D.C., Midtown Galleries Records \$f1932-1983, series II Exhibitions, box on Onondaga.

137 Royalty reciepts from May 31, 1947 to March 31, 1948 in the files from the Smithsonian Institution Archives of American Art, Washington, D.C., Midtown Galleries Records \$f1932-1983, series II Exhibitions, box on Onondaga. See Appendix F.

138 See Harper's Bazaar 81 (March 1947): 217; and "The News is in the Dark Print." Harper's Bazaar 81 (March 1947): 224; "Printed in Brown - Snuff, Ginger and Cinnamon." Harper's Bazaar 81 (March 1947): 226-227.

139 The following data was compiled from letters concerning royalty payments owed the artists from the onondaga Silk Company to Midtown Galleries on January 12, 1948 and April 30, 1948 . Full Figures are compiled in Appendix F.

140 A day dress of this period usually used $3-4$ yards of fabric while an evening dress would have used more. It should be noted that some of the material was also used for scarves and blouses which would have used only 1-2 yards of fabric. The samples found in this series that were of full width were between 40-41" wide between selvedges.

141 The total sales on record were 51,392 yards. This divided by 4 equals 12,848 . This is an estimate for the average number of dresses possibly produced, or able to be produced, from this series.

142 This estimate comes from an advertisement in the February 1947 issue of Harper's Bazaar for another dress by Jo Copeland of onondaga silk, as well as from the prices for other dresses produced by several of the other designers at this time in Harper's Bazaar 80-81 (October 1946-April 1947).

143 Sophie of Saks designed dresses which sold for $\$ 1500$ in 1938. Considering that this was ten years before this series of garments appeared, one can imagine the contemporary cost. ; see Milbank, p. 114 and Harper's Bazaar for pricing.

144 Smithsonian Institution Archives of American Art, washington, D.C., Midtown Galleries Records \$£1932-1983, series II Exhibitions, box on Onondaga.

145 Sample of the Davis print, "Children at Play," Smithsonian Institution Archives of American Art, Washington, D.C., Midtown Galleries Records \$f1932-1983, series V, box 2: fabric samples.

146 A list of those mentioned in the papers at the Smithsonian Institution Archives of American Art, washington, D.C., Midtown Galleries Records \$f1932-1983, series II Exhibitions, box on Onondaga, is located in Appendix $B$. 
147 "New Fabric Colors Copy Bird Plumage: Creations by Onondaga Silk Presented in Costumes by Nine Designers," New York Times (5 Aug 1947), p. 28.

148 Mendes and Hinchcliffe, p. 24.

149 Mendes and Hinchcliffe, p. 26; This view that has often appeared over the years in discussions of the process of textile design; Michael Ward, p. 24.

150 From an essay in the papers at the Smithsonian Institution Archives of American Art, Washington, D.C., Midtown Galleries Records $\$ f 1932-1983$, series II Exhibitions, box on Onondaga.

151 Ibid.

152 Harper's Bazaar (January 1947), p. 163.

153 Dior was mentioned for the first time in Harper's Bazaar in the April 1947 issue under the article "First Notes from the Paris Collections," p. 186.

154 Letters to Mr. A.D. Gruskin from W.R. Yerkes[sic], Acting Director, Board of Park Commissioners, City of Wichita, Kansas on February 26, 1947 requesting loan of exhibit; to Midtown Galleries from Marjorie S. Logan, Director of the Art Department, Milwaukee-Downer College on June 6, 1947 requesting loan of exhibit; to Miss Phoebe Hyatt, Chairman, Arts Committee, the Arts Club of Washington, Washington, D.C. from Midtown Galleries on June 13, 1947 concerning request for exhibit; to $C$. Moselle from A.D. Gruskin concerning catalog request by Mr. Paul Parker, Des Moines Art Center, Des Moines, Iowa on July 9, 1947; to Midtown Galleries from Sam Singal, Program Chairman, Augusta Art Club, Augusta, Georgia on July 12, 1947 requesting exhibit; from Charles Moselle to Mrs. Gruskin on August 11, 1947 concerning a request for exhibition by Mr. Bernard Frazier, Art Director, Philbrook Art Center; to Mr. Gruskin, Midtown Galleries from Mrs. Genevieve Bredo, Department of the Arts, College of Liberal Arts, University of New Hampshire, Durham, New Hampshire on November 5, 1947 requesting exhibition; to Midtown Galleries from Bishop Brown, Research Bureau for Retail Training, University of Pittsburg on November 12, 1947 requesting loan of exhibit. Smithsonian Institution Archives of American Art, Washington, D.C., Midtown Galleries Records \$f1932-1983, series II Exhibitions, box on Onondaga. 155 Robinson, p. 49. 
APPENDICES 
APPENDIX A

HISTORICAL REVIEW

The beginning of the following section highlights major political, social, and cultural events which influenced everyday life in the first half of the twentieth century. The atmosphere created by these events was reflected strongly in the arts and designs of this period. The second part explores the major influences on and participants in fashion design in the first half of the twentieth century and the resulting changes that occurred in women's garments.

\section{Design Influences in the Early Twentieth century}

The first decade of this new century combined both old and new ideas. England, France, Italy, Russia, and Germany had dominated the social, political, and economic stages in the western world for several centuries. Through their domination they influenced social and cultural standards. This was to slowly change with the start of the new century. ${ }^{1}$

One of the important factors in this change was the growth and solidarity of the working class. Another factor was the 
rise in the economic statuses of the above colonial powers. These and other factors added to an increasing restlessness of the colonial inhabitants who, as a result, challenged the established powers who had ruled political and economic life. Many colonial states started revolting against their parental governments no longer needing, or wanting, their economic or political governance. Western culture and standards were to fall in the face of new cultures and non-western standards. Eventually, the resulting confrontations and revolutions were to lead towards greater confrontation in world war I.2

Art and design in these early years followed several styles. Included among these were the styles established in the late nineteenth century as well as several new styles. ${ }^{3}$ The Arts and Crafts Movement of the late nineteenth century continued into the twentieth century. Western society also became fascinated with exotic, non-European cultures such as Turkish, Caucasian, Oriental and Indian cultures.4 Political unrest arising in colonial societies brought these cultures to the notice of Europe. The paintings of the "Fauves" include strange and exotic works such as those by Matisse and Gauguin. 5

The second decade was a time of increasing conflict. Between 1914-1919, world war I occupied the minds of many people. In 1917, Russia also became engulfed in political revolutions. 6 New forms of technology were adapted and used for fighting. Airplanes, tanks, and chemical gasses were used in addition to traditional forms of combat. ${ }^{7}$ Trade with England and Europe was hindered. The United States had a geographical 
advantage in this war and suffered less direct damage. As a result, the center of technological innovation and mass production began moving from England to the United States.8

People sought escape from the shadow of war through indulgence in foreign cultures and expression of new ideas through less traditional art forms and styles. Turkish, Caucasian, Oriental and Indian fads became full-blown. 9 These cultures continued to be highlighted in the political arena with unsuccessful attempts to gain independence from their rulers. ${ }^{10}$ Orientalism was a popular theme throughout fashion following the influence of Diaghilev's Ballets Russe and Scheherezade earlier in the century. ${ }^{11}$ These ballets had a great influence on social life as well as fashion for many years to come both in Europe and in the United States.

A focus was also turned towards American culture. ${ }^{12}$ The New York Armory Show in 1913 gave strong support to contemporary artistic endeavors. ${ }^{13}$ These endeavors included new forms of expression. Artists moved away from a focus on subject matter and turned their concentration to technique and form. ${ }^{14}$

Excess and post-war trauma preoccupied the minds of the whole world in the third decade. ${ }^{15}$ To some this period was referred to as the Roaring Twenties: a time for parties, flappers, fast cars, jazz and Hollywood glamour. To others, this was a period of recovery from the ravages of the First world war and the unrest it brought. ${ }^{16}$

In 1923, Lord Carnarvon discovered Tutankhamen's tomb in Luxor. As a result, Egyptian motifs began appearing everywhere: 
on clothing and manufactured objects, advertisements and publications. In 1925, American Jazz hit Paris with great success along with the Art Decoratifs Exhibition. The Art Deco period, as it came to be called, combined Cubism, Bauhaus, Expressionism with Egyptian, Aztec, and Russian influences. 17 Italy lent a neoclassical influence to design starting with Art Deco. The arts in general exhibited a geometric appearance. ${ }^{18}$ Among the great names in entertainment of this decade were Josephine Baker, Gloria Swanson, Pola Negri and Greta Garbo. 19 Then, in 1929, the stock market crashed in the United States, and the Great Depression hit everyone, worldwide. ${ }^{20}$ The United states had been the economic leader after world war I because of its technological power and available workforce, but its flirtation with greatness was short lived. Many of the wartorn countries were unable to repay money which had been loaned to them by the United states. 21

The thirties were the decade of economic and political concerns. There was a scramble to have war debts repaid. In the early thirties several import tariffs were placed on foreign items. ${ }^{22}$ Governments tried to help out-of-work artists by creating work and encouraging their participation in industry. ${ }^{23}$ In the United States the Federal Arts Project was established, while in Britain the Design and Industries Association was begun. 24

Surrealism gained momentum, perhaps questioning the role of reality in the world.25 Salvatore Dali was one of the leaders 
of this movement. Other forms of artistic expression included semi-abstraction, formal abstraction and biomorphism. ${ }^{26}$

A fascination with Hollywood stars and films took center stage from the beginning of the decade. The world was watching Fred Astaire and Ginger Rogers and listening to Duke Ellington and Louis Armstrong. Big bands and swing were strong. An effort was made to ignore the real difficulties of everyday life and bury them under entertainment. ${ }^{27}$

One of the major difficulties was that world war II was brewing. Hitler and Moussolini gained power in Germany and Italy, restructuring the economic stage for their own political purposes. Japan was examining its place in the political world. Spain was enveloped in civil war. In 1939, World War II broke out and lasted until $1945 .{ }^{28}$

By the beginning of the forties, the effect of war had begun to show itself. People were anxious to do something productive, perhaps to further themselves and to feel a part of the effort to win this second world war. Fitness crazes began to arise. ${ }^{29}$ Rationing had started and life took on a more rigid outward appearance. ${ }^{30}$

In the post-World war II era interest in technology, engineering, and science increased throughout the world. ${ }^{31}$ Immediately after World War II, the United States was the center of design.32 It again emerged from the war with fewer scars than Europe. ${ }^{33}$ Many European artists had emigrated to this country for political reasons during the war. ${ }^{34}$ 
By the early fifties the abstraction and biomorphism of the late forties developed into molecular and crystallo-graphic forms in art. This was a reaction to the advances in science, ${ }^{35}$ Functionalism and good design were also strong factors in production. ${ }^{36}$ The results can be seen in the large geometric shapes and motifs that emerged in art and design.

Eashion Design in the Early Twentieth Century

Just as in other artistic ventures, fashion design in the early years of the twentieth century continued to follow styles established in the late nineteenth century with only slight variations. Women's fashions were characterized by ankle-length skirts, high necklines, and corseted waists. ${ }^{37}$ Silhouettes of the first decade showed influences of the Arts and Crafts Movement in the emphasis on the S-shaped curve. ${ }^{38}$

Fashion and design were restrained during World war I. ${ }^{39}$ Couturiers throughout the world were faced with decreased quantities of fabrics with which to work; attention also turned towards the creation of practical, functional styles for the growing female workforce. ${ }^{40}$ The S-shaped figure which had been popular at the beginning of the nineteenth century had become slimmer by the beginning of World war I. Hemlines began to rise. Trousers and pants were not yet fashionable wear but became acceptable garments for women to wear at work. Couture houses functioning during the war included worth, Doucet, Lanvin, Paquin, Poiret, the Callots, Chanel, and Vionnet. ${ }^{41}$ 
In the late teens and early twenties, Paris was the center of fashion design.42 The effort to achieve a more modern, or contemporary, style grew.43 Italy lent a neoclassical influence to design.44 The discovery of King Tutankhamen's tomb in Egypt had an influence on fashion. Geometric shapes and designs appeared everywhere as a result of Art Deco. Styles became streamlined emphasizing a slim, straight boyish appearance. Waistlines dropped to the hipline. Sonia Delaunay, Hartnell, Schiaparelli, Chanel, Patou, and Galitzine were popular fashion designers. 45 Hollywood also began to have an influence on fashion styles. ${ }^{46}$ Not only was appearance important, but function and practicality began to play a more important part in clothing styles. Mid-way through the twenties sports clothes and short skirts appeared. ${ }^{47}$

The economic changes of the Great Depression influenced the fashion world. Import tariffs on foreign items encouraged lower cost custom-made knock-offs of designer models for the mass market. 48 Fashion leaders at this time were schiaparelli, Rochas, Molyneux, Patou, Lanvin, Adrian, Greer, Mainbocher, and Chanel. Hollywood was a strong force as inspiration for fashion, and its American designers gained status in the previously Paris-oriented world of fashion. ${ }^{49}$

By the end of this decade, styles had become severe with an almost military-like appearance. Shoulders began to broaden and waists narrowed.50 This was a significant change from the tubular silhouette of the teens and twenties. 
Paris, which had been the center of fashion design, was preoccupied with world war II between 1941 and 1945 but was still able to devote some of its energy to fashion design. Many couture designers had retired at the start of the war, leaving a gap in the industry which was only slowly filled by new names. The focus turned to America and its growing inexpensive readyto-wear industry. ${ }^{51}$ Function and utility were the driving forces of apparel design during the war years. Rationing of materials dictated tailored outfits and slim skirts. ${ }^{2}$ The average dress used only three to four yards of material.

In 1944, Paris was liberated, and fashion began to recover. ${ }^{53}$ Creativity in Paris centered on accessories more than apparel. Consumers in both Europe and the United States were buying selectively from the new, lower cost and more readily available ready-to-wear market. Yet, they had an urge for something different, a break from the utilitarian designs and a yearning to return to normalcy. ${ }^{54}$ Hemlines began to drop. ${ }^{55}$

One of the most influential new styles was the "New Look" created by Christian Dior in February 1947. This consisted of dresses with a round look made by curved shoulders, shaped bosoms, small waists and long, full skirts.56 Some of Dior's new styles consisted of as many as fifty yards of fabric in the skirt alone. ${ }^{57}$ Angles were no longer accentuated, and plainness and functionality were no longer the determiners of style.58 This was not an entirely new style, nor did it have an immediate impact on the whole world. ${ }^{59}$ Similar designs to 
Dior's "New Look" had been seen before the second world war, but clothes rationing and affordability of the quantities of fabric needed in these styles delayed their appearance. ${ }^{60}$ A major difference between Dior and other designers was that Dior had strong commercial backers from the industry and strong publicity helped make his designs known, overshadowing all others. ${ }^{61}$

slowly, frivolity and femininity arose again out of the practical effects on fashion of the depression and World war II. The restraint and formality of the previous years evaporated and softer lines emerged. By the early fifties, sports clothes and pants gained popularity for everyday wear. The fashion world adapted to the expanding role of women and the new evolving modern culture. 
LITERATURE CITED

1 L.V. Stavrianos, ed. The World since 1500: A Global History. 4th edition (New Jersey: Prentice-Hall, 1982), p. 511, 330-340.

2 Ibid.

3 Jonathan M. Woodham, Twentieth-Century Ornament, (New York: Rizzoli, 1990), p. 29

4 Georgina Howell, In Voque: Sixty years of international celebrities and fashion from British Voque, (New York: Schoken Books, 1976), p. 8 .

5 Horst de la Croix and Richard G. Tansey, Gardner's Art Through the Ages. 7 th ed. (New York: Harcourt Brace Javanovich, Inc., 1980), p. 810 .

6 Stavrianos, p. 343-369.

7 Hugh Thomas, A History of the World, (New York: Harper \& Row, 1982), p. 649-651.

8 Mary Schoeser, Twentieth Century Design Fabrics and Wallpapers, (London: Bell and Hyman, 1986), p. 22; Stavrianos, p. 367 .

9 Howell, p. 8.

10 Stavrianos, pp. $337-8,343,347-48,461,463-6$.

11 Woodham, p. 19.

12 Howell, p. 8.

13 de la Croix and Tansey, p. 810.

14 Barbara Rose, American Painting: The Twentieth Century,

(New York: Rizzoli International Pub., 1986), p. 21.

15 Howell, p. 49.

16 Thomas, p. 658 .

17 Howell, pp. 9, 45, $5154,59-60,78$.

18 Woodham, pp. $166,53$.

19 Howell, pp. 51, 54, 65, 78 .

20 Stavrianos, p. 387-8, 405, 412-422.

21 Thomas, p. 659.

22 Schoeser, p. 28.

23 Ralph Caplan, By Design, (New York: St. Martin's Press, 1982), pp. 34-35; Penny Sparke, An Introduction to Design and culture in the Twentieth century, (Boston: Allen and Unwin, 1986), p. 91 .

24 Oliver $W$. Larkin, Art and Life in America, (New York:

Holt, Rinehart and Winston, 1960), p. 409; Sparke, p. 82.

25 Howell, p. 106-7.

26 Lisa Philips and Bletter, Rosemarie Haag, eds., High Styles: Twentieth-Century American Design, (New York: Summit Books, 1985), p. xi; Woodham, p. 193; Stavrianos, pp. 116; Rose, p. 72 .

27 Howell, pp. 108, 114, 115, 132 . 
28 stavrianos, pp. 415-420, 424-426, 432 .

29 Howell, p. 112-114.

30 Diana DeMarley, The History of Haute couture 1850-1950, (New York: Holmes \& Meier Publishers, Inc., 1980), p. 197; Elizabeth Ewing, History of Twentieth Century Fashion (Totowa, N.J.: Barnes and Noble, 1986), p. 147; Howell, p. 185.

31 Phillips and Bletter, p. xi; Woodham, p. 193; Stavrianos, pp. 517-518.

32 Sparke, p. 156.

33 Stavrianos, p. 514 .

34 Rose, pp. 13, 60, 61.

35 Woodham, p. 193.

36 Heisinger, Kathryn B. and Marcus, George H. Design Since 1945. (New York: Philadelphia Museum of Art, 1983), p. x.

37 Ewing, p. 63

38 Woodham, p. 29 ; Ewing, p. 62 .

39 Howell, p. 1.

40 Tony and Claes Lewenhaupt, Crosscurrents:

Art, Fashion. Design 1890-1989, (New York: Rizzoli,1989), p. 54; Ewing, pp. 81-82, 91 .

41 Howell, pp. 1-2, 9-11, 12 .

42 Ewing, p.79, Howell, p. 5.

43 Lewenhaupt, p. 61.

44 woodham, p. 166.

45 Howell, pp. 9, 38, 45, 54, 55, 75, 78, 86, 96.

46 Ewing, p. 97.

47 Howell, pp. 82-85, 86 .

48 Schoeser, p. 28; Ewing, pp. 133, 147-148,

49 Howell, pp. 105, 108, 128, 132; Julian Robinson, Fashion in the 40s, (New York: St. Martin's Press, 1980), p. 7.

50 Howell 128, 132, 141 .

51 Ewing, p. 121; Robinson, p. 16.

52 Howell, p. 185; Robinson, p. 11, 20.

53 Howell, p. 189

54 Robinson, p. 55; Howell, p. 203.

55 Robinson, p. 39.

56 Robinson, p. 70; Ewing, p. 155.

57 De Marley, pp. 21, 24, 26.

58 Ewing, p. 115; Robinson p. 77.

59 De Marley, pp. 16, 30, 32; Harper's Bazaar April 1947.

60 De Marley, pp. 26, 27, 29, 31.

61 De Marley, pp. 17, 18; Robinson, p. 77. 
PAINTINGS AND DESIGNS SENT TO THE ONONDAGA SILK COMPANY BY THE MIDTOWN GALLERIES ${ }^{1}$

December 5, 1945

Julien Binford

Gladys Rockmore Davis

Dong Kingman

Waldo Peirce

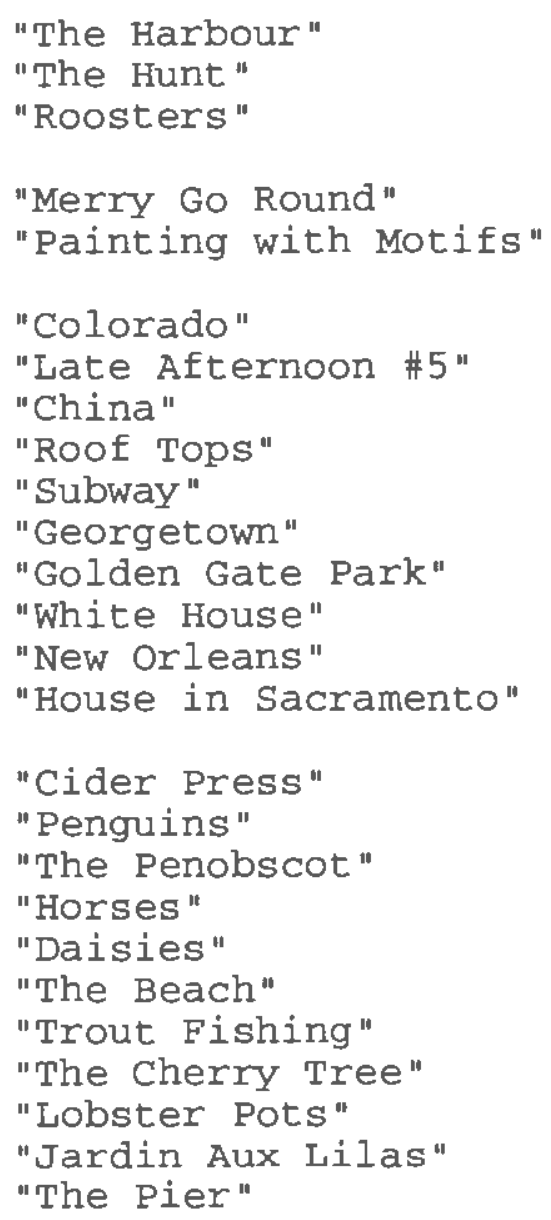


April 1, 1946

13 [unidentified] textile designs by Emlen Etting were sent from Midtown to Onondaga and returned

January 31,1947

waldo Peirce

"In the Park"

"Mandola and Music"

"Before the Concert"

"The Irish Harp"

"Music in the Air"

"Trio"

February 10,1947

Dong Kingman

"Fish"

"Fortune"

Gladys Rockmore Davis

"Jack and Jill"

"Puppet Show"

"Hearts and Flowers"

"Lady Godiva"

"May Pole"

February 13, 1947 (Designs listed as received by Onondaga; the artists were not identified)

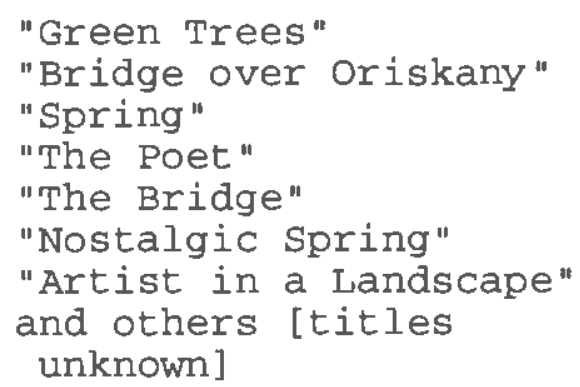

March 3, 1947 (Designs listed as received by Onondaga)

Lenard Kester

William Palmer

Dong Kingman [painting unidentified]

"Spring Winds"

"House by EL"

"Washington Monument" 
Waldo Peirce

Gladys Rockmore Davis
"My Shadow"

"Tom Piper"s Son"

"Clown with Flute"

"Three Witches"

"Summer Bathing"

"Hatchet Mt. Camp"

"Chamber Music"

"Wading"

"Ship's Prow"

"Puppets"

and others [titles unknown]

May 1, 1947

Julien Binford

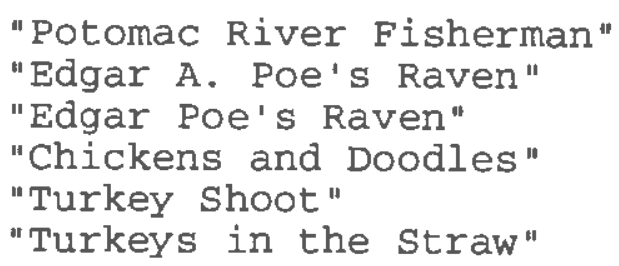

February 27, 1948

William Palmer

Dong Kingman

waldo Peirce

April 29, 1949

Lenard Kester

Dong Kingman

William Palmer

\author{
"The Road to the West" \\ "Vacation Pleasures" \\ "Gnarled Trees" \\ "Old Church" \\ "Conversation at Midnight" \\ "White Buildings" \\ "Trees" \\ "Wires" \\ "Chinatown" \\ "Daisies" \\ "On the Road to Penobscot"
}

"Early Spring"

"Birds"

"Central Park"

" Trees"

"Oriskany Valley"

"Fertile Moon" 
"Spring"

Gladys Rockmore Davis

William Thon

Henry Billings

waldo Peirce

May 6, 1949

Dong Kingman

February 21, 1950

Cecile Belle

William Thon

Dong Kingman

William Palmer

March 24, 1950

william Palmer
"Surging Spring"

"Rachmaninoff "

"Classical Remains"

"Italian Ruins"

"Olive Grove"

"Cyclamen"

"Black Birch"

"Water Bottles"

"Circus at Night"

"Downtown Brooklyn"

"Entrance to the EL"

"Park in the City"

"Things"

"Waterfront House"

"Bright Morning"

"Fading Flowers"

"Sicillian Boy"

"Roof Planes"

"Back Porch"

"Fortune Cover, 1950"

"Chinese Door"

"The Bridge"

"Lamppost "

"Lichen on the Rocks" "Oriskany Barns"

"Hilly Pasture"

"Spring Miracle"

"Ancient Wonder"

"Falling Leaves"

"Sumner Sunlight" 
May 11,1950
Henry Billings
8 designs [unidentified]
Cecile Belle
9 designs [unidentified]

June 7, 1950 (Items listed as returned to Midtown)

1 package Cecile Belle [paintings unidentified]

1 package containing: "Roof Planes"

"Hilly Pasture"

"Oskany [sic] Barns"

"Lichen on Rocks"

1 package containing 11 pictures [unidentified]

1 package containing: "Summer Sunlight"

"Party Tables"

[William Palmer]

"Falling Leaves"

"Ancient Wonder"

"Spring Miracle"

Fred Meyer

"Birds [or Buds] "

"Sulky Silk"

"Red Lion"

"Covered Columns"

"Butterfly collection"

"Leaf Motif"

"Canines"

William Thon

"Green Leaves "

"Piazza"

"Venice"

"Hill Town"

"Classical Remnants"

"Greek Temple"

"Flight "

"Aquatic Flora"

Other Kingman paintings sent to Onondaga:

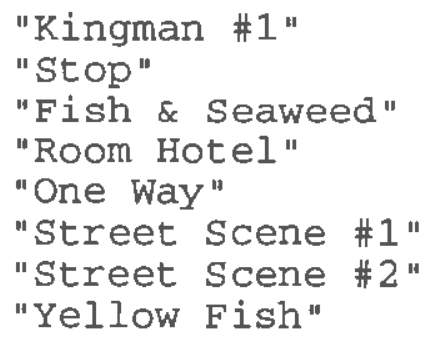


"Red Poppy"

"Columbus Circle"

"Birds and Transfer"

"Colorado Spring 42 "

Other Binford designs submitted to onondaga for consideration:

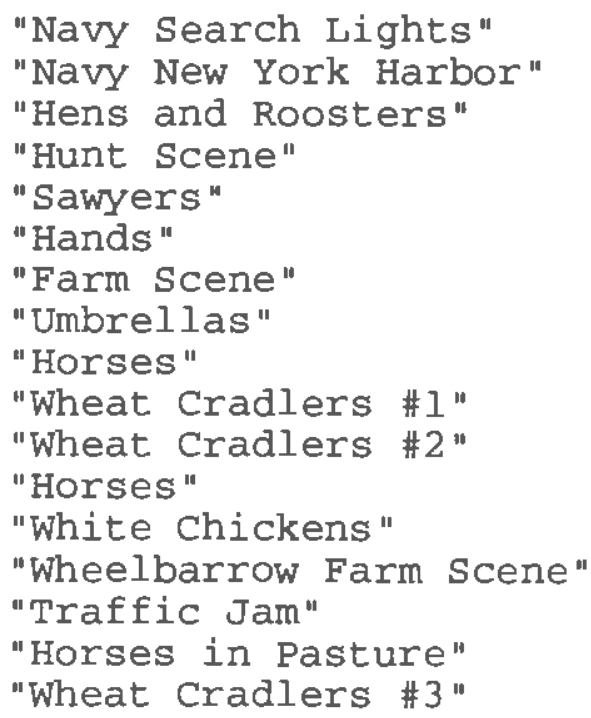

1 Smithsonian Institution Archives of American Art, Washington, D.C., Midtown Galleries Records \$11932-1983, series II Exhibitions, box on Onondaga. 


\section{EXTANT PAINTINGS, TEXTILE DESIGN SAMPLES, AND GARMENTS FROM THE "AMERICAN ARTIST PRINT SERIES"}

Artist, Title

Palmer

Horses and Corrals

Sun, water, and Air Horses

\section{Peirce}

Jardin Aux Lilas

Kittens at Play

Fish in Net

Trout Fishing

Cider Press

Sea Fantasy

Clouds and Trees

Kingman

New Orleans

Trees

Red Poppy

Chickens in squares

Davis

Ballet and Slippers

Carousel

Giselle

Rosenthal

Corn Foliage

Papayas

Papayas

Binford

White Chickens

Fine Creek Mills

Woman with a Hat

\section{Painting, Sketch or Drawing}

\author{
Textile \\ Sample
}

$A N^{*}$
$A N^{*}, A G^{*}$
$A N^{*}$
$A G^{*}$

$A^{*}, A G^{*}$

$\mathrm{AG}^{*}, \mathrm{NYT}^{\star}, \mathrm{NB}$

$A G^{*}$

$\mathrm{AN}^{*}, \mathrm{H}, \mathrm{P}$

A, R

$\mathrm{R}$

$\mathrm{AN}^{*}$

$\mathrm{R}$

$\mathrm{R}$

$\mathrm{C}, \mathrm{R}$

$\mathrm{R}$

CI

A

$A A^{*}$
$A G^{*}$
$A^{*}$
$G, P$

$A^{*}, A G^{*}$

$\mathrm{AN}^{*}$

$A G^{\star}$

$A^{*},{ }^{*}, G^{*}$

$A^{*}, P$

$A^{*}, R$

$A, R$
Garment or Garment Design 
APPENDIX D

BIOGRAPHIES OF ARTISTS INVOLVED WITH THE "AMERICAN ARTIST PRINT SERIES"

\section{Julien Binford}

Binford was born in 1908 in Fine Creek Mills, Virginia. He studied at Emory University, and the Art Institute of Chicago. The primary focus of Binford's work was his home state, Virginia, and her landscapes. His works include oils, acrylics, and watercolors. He received awards for his works from the Art Institute of Chicago; Virginia Museum of Fine Art, 1940; Virginia State Library; and the Rosenwald Foundation. At present, Binford resides in North Carolina. ${ }^{1}$

\section{Gladys Rockmore Davis}

Davis was born in New York City in 1901. She studied at the Chicago Institute of Art. She worked in the medium of pastels. Her subjects included theatrical and romantic images as well as storybook themes. Davis was recognized by the Art Institute of Chicago, 1937; William R. French Medal, 1937; Pennsylvania Academy of Fine Arts Purchase Prize, 1937; 
Recommendation Purchase Prize, 1938, from the Virginia Museum of Fine Arts; Pennsylvania Academy of Fine Arts Honorable Mention, 1939; Third Honorable Mention by the Corcoran Gallery of Art, 1939; Metropolitan Museum, 1940; Swope Museum, 1942; the National Academy of Design, 1944; Pepsi-Cola, 1946; the Pennsylvania Academy of Fine Arts Gold Medal, 1952; and the National Academy Gold Medal, 1955. She died in 1967.2

\section{Dong Kingman}

Kingman was born in Oakland, California in 1911. He spent some of his childhood in China. He studied art at the Lingman School, Hong Kong, and at the Fox \& Morgan Art School in Oakland. He taught in San Diego, San Francisco, Laramie at the University of Wyoming, and New York City at Columbia University. His works included watercolors, lacquer work, acrylics, illustrations, and murals. His most common subjects were cityscapes and related imagery. He designed a tapestry on commission in Hong Kong. Awards for his work include a San Francisco Art Association Prize, 1936; the Metropolitan Museum of Art Watercolor Exhibition \& American Watercolor Society Annual; Dolphin Medal Award, American watercolor Society, 1987; Paul Remmey Award, American watercolor Society, 1990; Mary Pleissner Award, American watercolor Society, 1991. He currently resides in New York City. ${ }^{3}$ 


\section{William Palmer}

William Palmer was born in Des Moines, Iowa in 1906. Palmer studied at the Art Student's League and the Ecole des Beaux Artes, France. He taught at Hamilton College and MunsonWilliams-Proctor Institute. He worked primarily on paintings and murals of New York State. Commissions he completed included murals for the Works Project Administration Fine Arts Project, 1939. He was recognized in his field by the National Academy of Design, 1947; the Paris Salon Medal, 1937; Audubon Artists, 1947; the American Institute of Arts and Letters Grant, 1953; and the Benjamin Altman Prize. ${ }^{4}$

\section{Waldo Peirce}

Waldo Peirce was born in Bangor, Maine in 1884. He studied at the Julian Academy, Paris, France as well as in Spain. He lived in Europe after the First World war but returned to the United States in 1930. His work frequently included impressionistic interpretations of allegorical themes in oil or watercolor. He was awarded the First Purchase Prize by Pomona College, 1933; First Purchase Prize by the Artists for Victory Portrait of America Contest by Pepsi-Cola, 1944; First Honorable Mention by the Carnegie Institute, 1944; First Purchase Prize in the Paintings of the Year Contest by Pepsi-Cola, 1948. Peirce died in 1970.5 


\section{Doris Rosenthal}

Rosenthal was born in Riverside, California. She studied art at Columbia University, with the Art Students League, and abroad. Besides painting, Rosenthal worked with lithography. Her subjects often focussed on Central American images and themes. She was recognized for her contribution to the art world with two Guggenheim Fellowships, 1931-32 and 1936-37; an American Academy of Arts and Letters Grant, 1952; by the Northwest Printmakers; by the National Academy of Design, 1952; and a Thomas B. Clark Award, 1952. She died in $1971 .{ }^{6}$ 
1 Peter Hastings, ed., Who was who in American Art (Connecticut: Sandview Press, 1985), p. 55; Glenn B. Opitz, Mantle Fielding's Dictionary of American Painters, Sculptors \& Engravers, 2nd ed. (Poughkeepsie, NY: Apollo Book, 1986), p. 72 ; correspondence with Patricia Chapin, Collections Manager, the New Britain Museum of Art (7 July 1993); and correspondence with Lisa Hummel Hancock, Registrar, The Virginia Museum of Fine Arts (20 July 1993).

2 Who Was who in America vol. 4 (Chicago: Marquis Who's Who, Inc., 1968), p. 233; Jim Collins and Glen B. Opitz, eds., Women Artists in America 18 th Century to the Present $(1790-1980)$ (Poughkeepsie, New York: Apollo, 1980).

3 "The Watercolor Series: Dong Kingman, "American Artist

(September 1947), pp. 42-3, 45.; Who's Who in American Art 198990 18th edition (New York: R.R. Bowker, 1989), p. 570; Who's Who in American Art 1993-94 20th edition (New York: R.R. Bowker, 1993), p. 629 .

4 Paul Cummings, Dictionary of Contemporary American

Artists, 3rd. edition (New York: St. Martin's Press, 1977), pp. 379-380; Hastings, p. 467; American Artists: An Illustrated Survey of Leading Contemporary Americans (New York: Facts on File Publications, 1985), p. 253.

5 National Cyclopedia of American Biography vol. 55, (New York: James T. White, 1974), p. 376; Who Was Who in America vol. 5 (Chicago: Marquis Who's Who, Inc., 1973), p. 562.

6 Collins and opitz, who was who in America vol. 5

(Chicago: Marquis Who's Who, Inc., 1973), p. 621. 


\section{APPENDIX E}

BIOGRAPHIES OF DESIGNERS INVOLVED WITH THE AMERICAN ARTIST PRINT SERIES "

Brownie of Foxbrownie

Miss Brownie of Foxbrownie designed expensive afternoon and evening clothes. These designs were available at stores such as A. Harris \& Company, Thalhimers, the May Company, and woolf Brothers. 1

\section{Bruno of Spectator_sports}

Bruno of spectator sports was rated among the best readyto-wear designers of the 1940s. His designs were available from Stix, Baer and Fuller.2

\section{Io Copeland of Pattullo}

Jo Copeland was born into the clothing business in New York. She was exposed to the trade through her father. She studied at both the Art Students League and the New York School of Fine and Applied Art. After working as a designer and fashion illustrator, she began designing part-time for the 
Pattullo Company, a wholesaler. In 1930, after achieving a full-time position in this establishment, she left to pursue a four-year wholesaling partnership with Ann Sadowsky. When this partnership ended, Copeland returned to Pattullo. She eventually become a partner of that firm and continued to design until 1970. Copeland died in 1982.

Copeland was considered an exceptionally talented American ready-to-wear designer and was frequently copied. She produced rather expensive, well-made clothing which tended to be formal rather than sporty. She preferred to design on figures following her own style rather than contemporary trends. Copeland worked with other Onondaga fabrics in addition those included in the "American Artist Print Series." Her designs were sold through Saks Fifth Avenue, Marshall Field and Company, Ransohoffs, the William H. Block Company, Montaldo's, NeimanMarcus, Frost Bros., Young-Quinlan, The Lindner Coy, and many other businesses during the late 1940s.3

\section{Madame Eta of Ren-Eta}

Mme. Eta was born Eta Valer Hentz of Budapest. Raised in Hungary, she studied at the Hungarian Royal state Academy of Industrial Arts. The company, Ren-Eta, which was established in the 1920s was the result of a partnership between Maurice Rentner and Madame Eta. In the 1930s, Mme. Eta established her own business with Ann Sadowsky.

Mme. Eta was considered a "top-of-the-line" ready-to-wear designer in the 1940s who created for the wholesale market. Her 
designs included several thematic collections such as Grecian classicism in 1943, Cape Cod in 1944, and the Middle Ages in 1945. Mme. Eta's designs were available through stores such as Bergdorf Goodman, Neiman-Marcus, and Lord \& Taylor. ${ }^{4}$

Emmet Joyce of Samuel Kass. Inc.

Emmet Joyce was born in Chicago. His education came from the Art Institute of Chicago. Eventually, Joyce moved from Chicago to New York and went to work for Hattie Carnegie. In 1928, he began a very successful wholesale business of his own. By 1935, Joyce had distanced himself from his company and was designing for Mme. Frances and Saks Fifth Avenue. He also worked at various times with sophie of saks on the "Saks originals" collection.

Joyce produced many day and evening clothes and often used purple and pink fabrics in his garments. He sold his ready-towear designs at Bergdorf Goodman, Jay-Thorpe and his own showroom. 5

\section{Morris Kraus of zuckerman and Kraus}

Kraus' designs sold through the company of zuckerman \& Kraus in the late 1940s. Ben zuckerman has gained more notice than Kraus in the history of American Fashion. ${ }^{6}$

\section{Sally Milarim}

Sally Milgrim designed for the Milgrim wholesale stores. By 1931, she had her own studio at Milgrim. She is known to 
have designed both ready-to-wear under the label "salymil" as well as for Milgrim. She also designed custom clothing and is known for her presidential inaugural gowns for the wives of Harding, Coolidge, and Roosevelt. Although Milgrim was a wholesale company, it rated among specialty shops in the 1930s.7

\section{Anna Miller}

Anna Miller was the sister of designer Maurice Rentner. Little has been written about her career beyond the 1959 merger of their two companies. ${ }^{8}$

\section{Ben Reig}

The Ben Reig company was founded in 1929 and mainly specialized in wholesale expensive coats and suits. Its main designer in the $1940 \mathrm{~s}$ and $1950 \mathrm{~s}$ was Omar Kiam. The apparel was carried by Lord \& Taylor, Marshall Field, Neiman-Marcus, and The Blum Stores. 9

\section{Nettie Rosenstein}

Nettie Rosenstein was born Nettie Rosencrans in Austria. She came to New York with her family in the 1890 s. Rosenstein began sewing at an early age. In 1916, she married saul Rosenstein. She began her own home-based business venture in 1919. By 1921, it had grown to 50 employees. At this time she also began wholesaling with I.Magnin. In 1929, Rosenstein temporarily retired from the apparel business but later returned to design for Corbeau et Cie. In 1931 Nettie Rosenstein worked 
with her sister Eva and Charles Gumprecht wholesaling under her own name. In 1961, Rosenstein moved away from garment design and focused more on her accessory designs. At this time, her sister began to design for other wholesalers.

Nettie Rosenstein's designs have been considered some of the best to come out of the ready-to-wear industry of the $1940 \mathrm{~s}$. Life magazine profiled Rosenstein in 1937 when the public began to look at the designers behind the company names. In 1938 Rosenstein won an award from Lord \& Taylor for her designs, and in 1947 she also won a coty Award. Her specialties were casual and formal evening clothes, often in black. Rosenstein preferred to design on the figure. Her designs often emphasized small waists contrasting with broad shoulder lines. Rosenstein worked with Onondaga fabrics on projects other than the "American Artist Print Series." Rosenstein's designs were carried by a single store in each city. Stores such as Kaufmann's; The Lindner Coy; Joske's of Texas; Saks Fifth Avenue; Carson, Pirie, Scott \& Company; Harzfield's; Montaldo's; and Holmes carried her line.10

\section{Sophie of Saks Fifth Avenue}

Sophie Gimbel, wife of Adam Gimbel, owner of Saks Fifth Avenue, commonly was known as Sophie of Saks. She was an inhouse designer whose exclusive designs were considered to have "the most expensive prices ever mentioned in the advertisements of the [1930] era."11 These prices averaged $\$ 125$. By 1938, her dresses ranged from $\$ 145-\$ 1500$. By 1947 Sophie was the 
cover story of Time magazine. Her designs included the exclusive made-to-order garments available at the Salon Moderne at Saks, the "Saks Originals" collection designed in collaboration with Emmet Joyce, the "sophie-gimbel" line and other ready-to-wear. Sophie Gimbel retired from designing in 1969. She died in 1981.12

Joset Walker of David M. Goldstein. Inc.

Joset walker was born in France. Her design education came by way of Broadway and Hollywood rather than Fifth Avenue. walker has been mentioned occasionally in the same breath as Claire McCardell. She was known as a wholesale designer of affordable sports clothes and casual wear for the more practical woman. A common feature of her dress designs during the late 1940 s was the drawstring waist. ${ }^{13}$ 
1 Caroline Reynolds Milbank, New York Fashion: The Evolution of American Style, (New York: Harry N. Abrams, Inc., 1989), p. 152; Harper's Bazaar (October 1946): 115; Harper's Bazaar (Nov 1946): 78; Harper's Bazaar (Dec 1946): 21; Harper's Bazaar (Feb 1947): 124; Harper's Bazaar (April 1947): 52, 111. 2 Milbank, p. 132 .

3 Milbank, p. 92, 95, 124, 132, 150, 186, 220; "Swing to Pleats." Harper's Bazaar (Feb 1947): 69; Harper's Bazaar

(October 1946): 13, 55, 84, 320; Harper's Bazaar (November 1946): 147; Harper's Bazaar (Feb 1947): 2, 6, 232; Harper's Bazaar (March 1947): 62, 63, 87 .

4 Milbank, p. 73, 132, 152; "Swing to Pleats." Harper's Bazaar 81 (February 1947): p.233.

5 Milbank, p. 114, 126

6 Harper's Bazaar (October 1946): p. 60; Harper's Bazaar (Jan 1947): p.43; Harper's Bazaar (February 1947): p.50, 52, 67; Harper's Bazaar (March 1947): p.64.

7 Milbank, p. 86, 116, 117, 119.

8 Milbank, p. 184

9 Milbank, p. 127, 163, 196, 231; Harper's Bazaar (October 1946): 26, 136; Harper's Bazaar (March 1947): 8, 55.

10 Milbank, p. 106, 124, 125, 132, 165; Harper's Bazaar (October 1946): 47, 66, 67, 108; Harper's Bazaar (Nov 1946): 46, 47; Harper's Bazaar (Dec 1946): 5; Harper's Bazaar (Jan 1947): 31; Harper's Bazaar (Feb 1947): 35, 81; Harper's Bazaar (March 1947): 4, 115 .

11 Milbank, p. 114.

12 Milbank, p. 114, 132, 165, 197, 243; Harper's Bazaar (October 1946): 210; Harper's Bazaar (April 1947): 173-174; "Fashion Designer Sophie Gimba1: Who Wants the New Look?, "Time (September 15, 1947): 87-92. 13 Milbank, p. 138, 166-167. 
APPENDIX F

QUANTITIES OF YARDAGE SOLD OF FABRICS FROM THE "AMERICAN ARTIST PRINT SERIES 1

\begin{tabular}{|c|c|c|c|c|c|c|}
\hline \multirow[b]{2}{*}{ Palmer } & $\begin{array}{l}\text { Total to } \\
5 / 31 / 47\end{array}$ & $\begin{array}{r}6 / 1 / 47- \\
12 / 31 / 47 \\
\end{array}$ & $\begin{array}{l}\text { Total to } \\
12 / 31 / 47\end{array}$ & $\begin{array}{l}1 / 1 / 47- \\
3 / 31 / 48\end{array}$ & \multicolumn{2}{|c|}{$\begin{array}{c}\text { Total to } \\
3 / 31 / 48\end{array}$} \\
\hline & & & & & & \\
\hline Horses and Corrals & $33831 / 8$ & 197 & $\begin{array}{lll}3580 & 1 / 8\end{array}$ & $2541 / 8$ & 3835 & \\
\hline Sun, Water, Air & $12116 / 8$ & $1013 / 8$ & $13131 / 8$ & $197 / 8$ & 1333 & \\
\hline \multicolumn{7}{|l|}{ Pierce } \\
\hline Cider Press & $15987 / 8$ & $2325 \quad 3 / 8$ & $3924 \quad 2 / 8$ & $1316 / 8$ & 4056 & \\
\hline Fish in Net & $9526 / 8$ & $10133 / 8$ & $19661 / 8$ & 16 & 1982 & $1 / 8$ \\
\hline Sea Fantasy & $11194 / 8$ & $971 \quad 6 / 8$ & $20912 / 8$ & $20463 / 8$ & 4137 & $5 / 8$ \\
\hline Kittens at Play & $678 \quad 4 / 8$ & $13 / 8$ & $6797 / 8$ & $895 / 8$ & 769 & $4 / 8$ \\
\hline Jardin Aux Lilas & $8452 / 8$ & $\ldots$ & $845 \quad 2 / 8$ & $-\ldots$ & 845 & $2 / 8$ \\
\hline Trout Fishing & $38432 / 8$ & --- & $3843 \quad 2 / 8$ & --- & 3843 & $2 / 8$ \\
\hline $\begin{array}{c}\text { Trees [Clouds } \\
\text { and Trees] }\end{array}$ & $16502 / 8$ & $13 / 8$ & $16515 / 8$ & $632 / 8$ & 1714 & $7 / 8$ \\
\hline \multicolumn{7}{|l|}{ Kinoman } \\
\hline Red Poppies & $21187 / 8$ & 5 & $21237 / 8$ & 18 & 2141 & $7 / 8$ \\
\hline New Orleans & $11133 / 8$ & $17304 / 8$ & $28437 / 8$ & $694 / 8$ & 2913 & $3 / 8$ \\
\hline Chickens in squares & $1327 \quad 7 / 8$ & $215 / 8$ & $13494 / 8$ & $2724 / 8$ & 1622 & \\
\hline Trees & $13507 / 8$ & $12946 / 8$ & $2645 \quad 5 / 8$ & ---- & 2645 & $5 / 8$ \\
\hline \multicolumn{7}{|l|}{ Davis } \\
\hline Ballet slippers & $13334 / 8$ & --- & $13334 / 8$ & ---- & 1333 & $4 / 8$ \\
\hline Giselle & $8825 / 8$ & $12 / 8$ & $8837 / 8$ & $25 \quad 5 / 8$ & 858 & $2 / 8$ \\
\hline Carousel & $10197 / 8$ & $154 \quad 4 / 8$ & $11743 / 8$ & ---- & 1174 & $3 / 8$ \\
\hline \multicolumn{7}{|l|}{ Rosenthal } \\
\hline $\begin{array}{c}\text { Tropical Foliage } \\
\text { [Papayas] }\end{array}$ & $7766 / 8$ & $196 / 8$ & $7964 / 8$ & $573 / 8$ & 853 & $7 / 8$ \\
\hline Papayas & 1010 & $1813 / 8$ & $11913 / 8$ & 20 & 1211 & $3 / 8$ \\
\hline Corn Foiliage & $17113 / 8$ & $50 \quad 5 / 8$ & $17616 / 8$ & 20 & 1781 & $6 / 8$ \\
\hline \multicolumn{7}{|l|}{ Binford } \\
\hline Woman with a Hat & $17691 / 8$ & 48 & $1817 \quad 1 / 8$ & 15 & 1832 & $1 / 8$ \\
\hline Fine Creek Mills & $24457 / 8$ & 127 & $2572 \quad 7 / 8$ & $-\cdots$ & 2572 & $7 / 8$ \\
\hline White Chickens & $75331 / 8$ & $1842 / 8$ & $7717 \quad 3 / 8$ & 214 & 7931 & $5 / 8$ \\
\hline
\end{tabular}

1 Smithsonian Institution Archives of American Art, Washington, D.C., Midtown Galleries Records \$f1932-1983, series II Exhibitions, box on Onondaga. 
APPENDIX G

LIST OF INSTITUTIONS CONTACTED

Museums and archives contacted in search of representations of textiles or clothing from the Onondaga "American Artist Print Series, 1947" include:

The Addison Gallery of Art, Andover, Massachusetts*

The Archives of American Art, Washington, D.C.*

The Art Institute of Chicago, Chicago, Illinois*

The Brooklyn Museum, Brooklyn, New York

The Cleveland Museum of Art, Cleveland, Ohio*

The Dayton Art Institute, Dayton, Ohio*

The Fashion Institute of Technology, New York*

The Fort Wayne Museum of Art, Fort Wayne, Indiana*

The Goldie Paley Gallery, Moore College of Art and Design, Philadelphia, Pennsylvania*

The Goldstein Gallery, the University of Minnesota, St. Paul, Minnesota*

The Helen Allen Textile Collection, the University of wisconsin, Madison Wisconsin*

The High Museum of Art, Atlanta, Georgia*

The Kalamazoo Institute of Art, Kalamazoo, Michigan*

The Memorial Art Gallery of the University of Rochester, Rochester, New York*

The Memphis Brooks Museum of Art, Memphis, Tennessee*

The Metropolitan Museum of Art, New York*

The Midtown Galleries, New York* (referred to the Archives of American Art which holds their records)

The Munson-Williams-Proctor Institute, Utica, New York*

The Museum of Fine Art, Boston, Massachusetts

The New Britain Museum of Art, New Britain, Connecticut* 
The Philadelphia College of Textiles and Science, Philadelphia, Pennsylvania*

The Philadelphia Museum of Art, Philadelphia, Pennsylvania*

The Saint Louis Art Museum, St. Louis, Missouri*

The Scalamandre Museum of Textiles, New York

The Springfield Museum of Art, Springfield, Missouri

The Toledo Museum of Art, Toledo, Ohio*

The Virginia Museum of Art, Richmond, Virginia*

Queries were placed in the following publications:

The Textile Society of America Newsletter The Costume Society of America Newsletter ITAA Newsletter

In search of information on the Onondaga Silk Company inquiries were also made of:

Ford, Bacon \& Davis, Inc., Clifton, New Jersey The Museum of American Textile History, North Andover, Massachusetts*

The Easton Public Library, Easton, Pennsylvania

The Northampton County Historical and Genealogical Society, Easton, Pennsylvania

In search of the educational color film made in conjunction with the American Artist Print Series exhibit inquiries were made of:

The American Archives of the Factual Film, Iowa State University*

The Art on Film Database Service, New York*

The Library of Congress, Washington, D.C.* 
The following collections contain samples of the textiles and garments from the Onondaga series (see Appendix III for details):

The Archives of American Art, Washington, D.C. The Cleveland Museum of Art, Cleveland, Ohio The Metropolitan Museum of Fine Art, New York The Museum of the Rhode Island School of Design

The following institutions contain paintings and representations of paintings which inspired the textile prints by Onondaga (see Appendix III for details):

Addison Gallery of Art, Phillips Academy, Andover, Massachusetts The New Britain Museum of Art, New Britain, Connecticut

Furthermore, I would like to thank Mary Gruskin for corresponding with me about her role in the collaboration.

* Indicates response to correspondence 
BIBLIOGRAPHY

\section{Primary Sources}

"A Matter of Good Form." Harper's Bazaar 81 (January 1947): 163.

"Art into Living: Silk Prints 1947," Art News, 45(11): 34-38+.

"Birth of a New Summer Dress." Harper's Bazaar 81 (May 1947): 147 .

Davison's Textile Blue Book. Ridgewood, N.J.: Davison Publishing Company, Inc., 1945-55.

"Fashion Designer Sophie Gimbal: Who Wants the New Look?" Time (September 15, 1947): 87-92.

"First Notes from the Paris Collections." Harper's Bazaar 81 (April 1947): 186-187.

"From a Kingman watercolor into a Silk Print for Onondaga," American Artist, March 1947: 44-46.

Frost, Rosamund. "Silk in Search of Six Painters," Art News, $45(11): 30-33+$.

Grafly, Dorothy. "Industrial Design," Design, 48 (5) January 1947: 16, 23.

Harper's Bazaar 81 (March 1947); 188, 217.

Kingman, Dong. "The Making of a Watercolor" in The Watercolors of Dong Kingman, and How the Artist Works, pp. 113-133. New York: The Studio Publications, Inc., 1958. 
"Lines from Balenciaga." Harper's Bazaar 80 (December 1946): 184 .

"Mill Notes," American wool and cotton Reporter, July 9. $1925: 75$.

"Mi11 Notes," American Wool and Cotton Reporter, December 17,1925 .

"New Fabric Colors Copy Bird Plumage: Creations by Onondaga Silk Presented in Costumes by Nine Designers, "New York Times, 5 Aug 1947, p. 28.

New York Times, 2 April 1930, p. 51.

"Outlines of New Lines." Harper's Bazaar 81 (May 1947): $130-131$.

"Paintings and Fabrics Now on Display Here: Art Inspired Fashions Are At Brooks Gallery, "The Commercial Appeal, Memphis, Sunday Morning, 14 March 1948.

"Paris: Dior Presents-." Harper's Bazaar 81 (April 1947): 188 .

"Paris: Night Silhouettes." Harper's Bazaar 81 (April 1947) : 192-3.

"Paris Openings." Harper's Bazaar 80 (October 1946): 224, 406 .

"Paris Takes a New Line." Harper's Bazaar 80 (November 1946): 211-213.

"Paris Creates for Dramatic Settings." Harper's Bazaar 80 (November 1946): 214 .

Payant, Felix. "Design in America." Design 48:(3) November, $1946: 3$.

Pope, Virginia. "Figured Silks and Rayons Exhibited with Art Works that Provided Motifs," New York Times, Dec. 17,$1947 ; 41$.

"Printed in Brown - Snuff, Ginger and Cinnamon." Harper's Bazaar 81 (March 1947): 226-227.

"Silhouette Insurance." Harper's Bazaar 81 (March 1947): 262 . 
Stone, Orra L. History of Massachusetts Industries: Their Inception, Growth and Success, vol. 1. Boston: The S.J. Clarke Publishing Co., 1930: 215.

"Strides Toward Better Design in Industry: Onondaga Silks American Artist Print Series," Design, 48(6): 2 .

"Swing to Pleats." Harper's Bazaar 81 (February 1947): 232233 .

"Textile Cos. Helped by Outside Experts: Silk and Woolen Makers were Taken over by Managers Not in Business, Straight-Line Plan Used, Brought Big Savings for Onondaga, Hamilton Changed Its output and Reorganized Plant," New York Times, 20 July 1930, sec. N, p. 19.

"Textile Design and the Artist," Desion. 48(6): 22.

"Textile Panorama," Museum Notes, Museum of Art Rhode Island School of Design, Providence, R.I. 5(3), April 1947 .

"Textile Panorama: Ancient and Modern," Museum Notes, Museum of Art Rhode Island School of Design, Providence, R.I. 5(2), February, 1947.

"Textile Show At Institute Is Described As Refreshing," Dayton Daily News, 7 September 1947.

"The Ankle Length has Caught on." Harper's Bazaar 81 (April 1947): 201.

"The Fine Seam and the Grand Manner." Harper's Bazaar 81 (April 1947): 180.

"The News is in the Dark Print." Harper's Bazaar 81 (February 1947): 224 .

"The Private Life of A Woman of Elegance." Harper's Bazaar 80 (October 1946): 206-207.

"The Watercolor Series: Dong Kingman," American Artist. September 1947: cover, 42-45.

A Woman of Fashion, 1947 Spring-Summer. New York: Bloomingdale Bros., 1947:32-34. 
Extant Textiles

Cleveland, Ohio. The Cleveland Museum of Art. Textiles: 47.105.109 .

New York, New York. The Metropolitan Museum of Art. The Costume Institute. Textiles: CI47.74.16abcd, CI47.74.17abc, CI47.74.92ab.

Providence, Rhode Island. The Textile collection of The Museum of Art, Rhode Island School of Design. Textiles:

RISD $47.113-.129$.

Washington, D.C. Smithsonian Institution Archives of American Art. Midtown Galleries Records $\$ f 1932-1983$, series II

Exhibitions, box 3 on Onondaga; series V, box 2: fabric samples; series VI, box 6: photographs.

\section{Archival Materials}

Andover, Massachusetts. Addison Gallery of Art, Phillips Academy. Archive file on the Onondaga silks exhibited in connection with "Miscellaneous Textiles" exhibition April 2-May 31948.

Saint Louis, Missouri. The Saint Louis Art Museum. Archives. Exhibition Files: Silk in Search of Six Painters, 1947.

Washington, D.C. Smithsonian Institution Archives of American Art. Midtown Galleries Records \$fl932-1983, series II Exhibitions, box 3 on Onondaga; series $v$, box 2 : fabric samples; series VI, box 6: photographs.

\section{Secondary sources}

American Artists: An Illustrated Survey of Leading Contemporary Americans. New York: Facts on File Publications, 1985: 253. 
Blausen, Whitney. "Ruth Reeves' 'Personal Prints:' Printed Textiles from the $1930 \mathrm{~s}$ and 1940s." Proceedings of the Third Biennial Symposium of the Textile Society of America. Seattle, Washington: n.p., September 24-26, 1992, pp. 163167 .

Blum, Stella. Everyday Fashions of the Thirties, as pictured in Sears Catalogs. New York: Dover Publications, Inc., 1986.

Caplan, Ralph. By Design. New York: St. Martin's Press, 1982.

Carlano, Marianne and Shilliam, Nicola J. Early Modern Textiles: From Arts and Crafts to Art Deco. Exhibition and Catalogue. Boston: Museum of Fine Arts, 1993.

Carpenter, James M. Visual Art: A Critical Interpretation. New York: Harcourt, Brace, Jovanovich, 1982.

Castleman, Riva, ed. Art of the Forties. New York: Harry N. Abrams, Inc., 1991.

Clarke, Hazel. Textile Printing. Aylesbury: Shire Publications, Ltd., 1985.

Collins, Jim and Opitz, Glen B., eds. Women Artists in America 18th century to the Present (1790-1980). Poughkeepsie, New York: Apollo, 1980.

Cummings, Paul. Dictionary of Contemporary American Artists, 3rd. edition New York: St. Martin's Press, 1977: p. 379-380.

de la Croix, Horst and Tansey, Richard G. Gardner's Art Through the Ages. 7 th ed. New York: Harcourt Brace Javanovich, Inc., 1980.

De Marley, Diana. The History of Haute Couture 1850-1950. New York: Holmes \& Meier Publishers, Inc., 1980.

Duncan, Alstair. The Encyclopedia of Art Deco. New York: E.P. Dutton, 1988.

Elizabeth Ewing, Elizabeth. History of Twentieth Century Fashion. Totowa, N.J.: Barnes and Noble, 1986.

Falk, Peter Hastings, ed. Who Was who In American Art. connecticut: Soundview Press, 1985: 55, 467. 
Ferrier, Jean-Louis. Art of our Century. New York: Prentice Hall, 1989: 851, 853.

Goodrich, Lloyd and John I.H. Baur. American Art of our

Century. Frederick A. Praeger Publishers, 1961.

Gotshalk, D.W. Art and the Social order, 2nd ed. New York: Dover Publications, 1962: 201-217.

Gruskin, Alan D. "The Story of the Artist" in The Watercolors of Dong Kingman, and How the Artist Works, pp. 21-61. New York: The Studio Publications, Inc., 1958.

Hastings, Peter ed. Who Was who in American Art. Connecticut: Sandview Press, 1985: 55.

Heisinger, Kathryn B. and Marcus, George H. Design Since 1945. New York: Philadelphia Museum of Art, 1983.

Howell, Georgina. In Voque: Sixty vears of international celebrities and fashion from British voque. New York: Schocken Books, 1976.

Hulick, Diana Emery. Waldo Peirce: A New Assessment 1884-1970, Essay by Robert F. Brown. Orono: University of Maine, 1984.

Jenkins, Iridell. Art and the Human Enterprise. Cambridge: Harvard University Press, 1958: 1-22, 291-305.

Johnston, Meda Parker and Glen Kaufman. Design of Fabrics. New York: Reinhold Publishing Corp., 1967.

Joseph, Marjory. An Introduction to Textile Science. New York: Holt, Rinehart and Winston, 5th ed, 1986.

Knecht, Edmund and James Best Fothergill. The Principles and practice of Textile printing. London: Charles Griffin and Company, Ltd, 1952, p. 69.

Larkin, oliver W. Art and Life in America. New York: Holt, Rinehart and winston, 1960: 405-479.

Lewenhaupt, Tony and Claes Lewenhaupt. Crosscurrents: Art,Fashion, Desion 1890-1989. New York: Rizzoli,1989, p. 54 .

Lucie-Smith, Edward. Movements in Art Since 1945. Thames and Hudson, 1985: 25-33. 
Mendes, Valerie D. and Frances M. Hinchcliffe. Ascher: Fabric, Art, and Fashion. Cambridgeshire: Balding and Mansell, Ltd., 1987.

Milbank, Caroline Reynolds. New York Fashion: The Evolution of American Stvle. New York: Harry N. Abrams, Inc., 1989 .

Morton, Grace Margaret. The Arts of Costume and Personal Appearance, 3rd ed., New York: John Wiley and Sons, Inc., 1966, pp. 67-116.

National Cyclopedia of American Biography, vol. 55, New York: James T. White, 1974: 376.

Opitz, Glenn B. Mantle Fielding's Dictionary of American Painters, Sculptors \& Engravers, 2nd ed. Poughkeepsie, NY: Apollo Book, 1986, p. 72.

Parry, Linda. Textiles of the Arts and Crafts Movement. London: Thames and Hudson, 1988.

Paz, Octavio. "Seeing and Using: Art and Craftsmanship" in Convergences: Essays on Art and Literature by Octavio Paz, trans by Hele Lane, New York: Harcourt, Brace, Javanovich, 1987: 50-67.

Phillips, Lisa and Bletter, Rosemarie Haag, eds. High Styles: Twentieth-Century American Design. New York: Summit Books, 1985.

Reeder, Jan. "Society on Silk: Prints from the 1920s and 30s," Paper presented at the Fashion Institute of Technology. New York City, April 261993.

Robinson, Stuart. A History of Printed Textiles.

Cambridge, Ma.: The MIT Press, 1969.

Robinson, Julian. Fashion in the 40s. New York: St. Martin's Press, 1980.

Rose, Barbara. American Painting: The Twentieth Century. New York: Rizzoli International Pub., 1986.

Saroyan, William. "The Eye and Hand of Dong Kingman" in The Watercolors of Dong Kingman, and How the Artist Works, pp. 7-14. New York: The Studio Publications, Inc., 1958. 
Schoeser, Mary. Twentieth Century Design Fabrics and Wallpapers. London: Bell and Hyman, 1986.

Schoeser, Mary and Celia Rufy. Enqlish and American Textiles from 1790 to the Present. New York: Thames and Hudson, 1989: 169-201.

Schwalback, Mathilda A. and James A. Screen-Process Printing. New York: Van Nostrand and Reinhold Co., 1970 .

Sparke, Penny. An Introduction to Design and culture in the Twentieth Century. Boston: Allen and Unwin, 1986.

Stavrianos, L.V. , ed. The World since 1500: A Global History, 4th ed. New Jersey: Prentice-Hall, 1982: $343-$ $369,423-461$.

Thomas, Hugh. A History of the World. New York: Harper \& Row, 1982 .

Ward, Michael. Art and Design in Textiles. New York: Van Nostrand Reinhold Company, 1973.

Who's who in American Art 1989-90, 18th edition. New York: R.R. Bowker, 1989: 570 .

Who's who in American art 1993-94, 20th edition. New York: R.R. Bowker, 1993: 467, 629 .

Who was who in America, vol. 4. Chicago: Marquis who's who, Inc., 1968: 233 .

Whe was who in America, vol. 5. Chicago: Marquis who's who, Inc., 1973: 562, 621 .

Woodham, Jonathan M. Twentieth-Century Ornament. New York: Rizzoli, 1990. 